\title{
Steps toward an improvement in process-based models of water use by fruit trees: A case study in olive
}

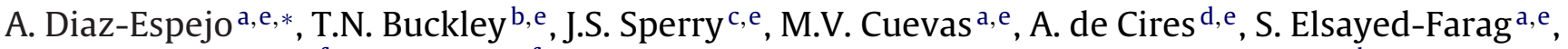 \\ M.J. Martin-Palomo f,e , J.L. Muriel ${ }^{\text {f,e }}$, A. Perez-Martin ${ }^{\mathrm{a}, \mathrm{e}}$, C.M. Rodriguez-Dominguez $^{\mathrm{a}, \mathrm{d}, \mathrm{e}}$, \\ A.E. Rubio-Casal ${ }^{\text {d,e }}$, J.M. Torres-Ruiz ${ }^{\text {a,e }}$, J.E. Fernández ${ }^{\text {a,e }}$
}

\footnotetext{
a Instituto de Recursos Naturales y Agrobiología, IRNAS-CSIC, Apartado 1052, 41080 Sevilla, Spain

b Department of Biology, Sonoma State University, 1801 E Cotati Ave, Rohnert Park, CA 11 94928, USA

${ }^{\mathrm{c}}$ Department of Biology, University of Utah, 257S 1400E, Salt Lake City, UT 84112, USA

d Departamento de Biologia Vegetal y Ecologia, Universidad de Sevilla, Sevilla, Spain

e ETSIA, Departamento de Ciencias Agroforestales, Universidad de Sevilla, Sevilla, Spain

${ }^{\mathrm{f}}$ IFAPA, Centro Las Torres-Tomejil, Junta de Andalucía, Alcala del Río, Sevilla, Spain
}

\section{A R T I C L E I N F O}

Article history:

Available online xxx

\section{Keywords:}

Stomatal conductance model

Drought

Olea

Vulnerability curve

Root length density

Irrigation

\begin{abstract}
A B S T R A C T
We applied two process-based models in a hedgerow olive orchard with the aim of understanding the limitations and mechanisms behind the control of transpiration in olive trees under drip irrigation. One model is based on the biophysics of water flow through the porous media of soil and xylem. The other is a hydromechanical model based on the observed dependence of stomatal aperture on whole-plant and epidermis water relations. The experiments were made in a hedgerow olive orchard ( 1667 trees ha $\left.{ }^{-1}\right)$ planted with 5-year-old 'Arbequina' trees. Measurements were made in control trees irrigated to replace $100 \%$ of the crop water needs, and in trees under regulated deficit irrigation (RDI) strategy, in which irrigation replaced ca. $30 \%$ of the control. Soil physical properties, root distribution, leaf area, sap flow, leaf osmotic pressure and key variables of leaf gas exchange and water status were measured and models were applied. Results show how in our orchard, with a shallow root distribution and very coarse soil, most of the limitation to transpiration was imposed by the hydraulics of the rhizosphere. The model shows how this limitation was related to the ratio of root to leaf area, and how this ratio can be managed by canopy pruning or by changing the number of drippers. Likewise, osmotic adjustment occurred similarly in both irrigation treatments, despite differences found on leaf water potential. Water stress largely affected plant hydraulic conductivity of RDI trees. A potential involvement of regulating signals, other than purely hydraulics, was evident in both treatments, although our data suggests that these signals were not regulated by the soil water status only.
\end{abstract}

(C) 2012 Elsevier B.V. All rights reserved.

\section{Introduction}

The main challenge for precision agriculture in fruit trees in arid and semi-semiarid environments is the optimal management of irrigation. Two main approaches are being widely used with that purpose: the crop coefficient approach, also known as the FAO-56 approach, based on the Penman-Monteith equation to calculate the atmospheric demand and on the use of crop coefficients adapted to the orchard conditions (Allen et al., 1998); and the use of plantbased methods for a precise monitoring of the trees' water stress (Fernández and Cuevas, 2010). In the first case, large uncertainties arise when equations are applied in different scenarios where soil conditions, phenological stages, orchard age, etc. vary (Pardossi

\footnotetext{
* Corresponding author. Tel.: +34 9546247 11x174; fax: +34 954624002 .

E-mail address: adiaz@irnase.csic.es (A. Diaz-Espejo).
}

and Incrocci, 2011). On top of that, the use of monthly values of the crop coefficient limits the temporal precision of this approach (Fernández and Moreno, 1999). The need for deficit irrigation in most fruit trees orchards (Fereres and Soriano, 2007; Ruiz-Sanchez et al., 2010) has driven substantial development of plant-based methods in recent decades. These methods can be used for the continuous and automatic monitoring of plant water stress, so they have a potential for high precision irrigation. A variety of sensors are used, including those related to measurements of sap flow (Fernández et al., 2008a), trunk diameter variations (Fernández and Cuevas, 2010; Ortuño et al., 2010), leaf turgor pressure (Fernández et al., 2011), water content in the trunk (Nadler and Tyree, 2008), electric water potential (Oyarce and Gurovich, 2011) and canopy temperature (Jones, 1999). Plant-based methods have the potential advantage of measuring the plant's response to the prevailing environmental conditions. The outputs, therefore, have a physiological basis, although their interpretation and application present 
challenges. Using these outputs to generate a measure of the degree of stress suffered by the plant, in order to apply management decisions, remains the main challenge.

However, another approach has received some attention as well: physiologically based models. Modeling plant transpiration requires successful modeling of stomatal conductance, especially in fruit trees with a low decoupling factor (Jarvis and McNaughton, 1986) where transpiration is effectively controlled by stomata. Models of stomatal conductance have been approached from empirical (Jarvis, 1976; Ball et al., 1987; Leuning, 1995) and mechanistic points of view (Jarvis and Davies, 1998; Dewar, 2002; Gao et al., 2002; Buckley et al., 2003; Peak and Mott, 2011). However, the main challenge remains incorporating the effect of water stress in the models (Damour et al., 2010; Egea et al., 2011). In addition to the importance of stomatal conductance, another key variable usually ignored in modeling fruit tree transpiration, and directly related to water stress and drought, is soil and plant hydraulic conductivity. Soil and xylem conductivity both decrease under hydraulic tension, and these decreases can be described well with physically based "unsaturated conductivity curves" (for soil) or "vulnerability curves" (for xylem). Improving the representation of soil and xylem hydraulics in models of crop water use is necessary to achieve a mechanistic link between soil water availability and canopy water use (Sperry et al., 2002). The present study will assess the ability of two process-based models - the Sperry et al. (1998, hereafter SACC) model of hydraulic limits and the Buckley et al. (2003, hereafter BMF) model of stomatal conductance - to inform management of water use in a hedgerow olive orchard. Our results demonstrate the central role played by the rhizosphere in the hydraulic limitation of transpiration in this orchard. This limitation can be partially managed by farmers if leaf area (pruning practices) and number of drippers in the irrigation system are modified. Moreover, our results show how much both hydraulic and non-hydraulic signals are involved in the control of transpiration by stomata.

\section{Material and methods}

\subsection{Study site and orchard characteristics}

The experiments were made in 2011 at the Sanabria orchard, a hedgerow olive commercial orchard at $25 \mathrm{~km}$ to the west of Seville, southwest Spain $\left(37^{\circ} 15^{\prime} \mathrm{N},-5^{\circ} 48^{\prime} \mathrm{W}\right)$. The trees, 5year-old Olea europaea L. 'Arbequina', was planted at $4 \mathrm{~m} \times 1.5 \mathrm{~m}$ ( 1667 trees ha $\left.^{-1}\right)$. They had a single trunk with branches from 0.6 to $0.7 \mathrm{~m}$ above ground and the rows, $2.40 \mathrm{~m}$ tall and $1.96 \mathrm{~m}$ wide, run $\mathrm{N}-\mathrm{NE}$ to S-SW. The area has a Mediterranean climate, with a mild, wet season from October to April and a hot, dry season for the rest of the year. Yearly average precipitation $(P)$ and potential evapotranspiration $\left(\mathrm{ET}_{\mathrm{O}}\right.$ ) are $525.9 \mathrm{~mm}$ and $1542.4 \mathrm{~mm}$, respectively (period 2002-2011).

The experimental design was a randomized complete block design with four $12 \mathrm{~m} \times 16 \mathrm{~m}$ plots per treatment. Each plot contained 8 central trees surrounded by 24 border trees. All measurements were made on the central trees of each plot. Two irrigation treatments were imposed in the orchard: a control treatment where irrigation fulfilled tree water demand, and a regulated deficit irrigation treatment in which only $30 \%$ of the water added to control was applied (30RDI). The irrigation amounts (IA) supplied to this treatment varied according to the sensitivity to water stress of the crop at each phenological stage. Daily irrigation to replace $100 \%$ of the irrigation needs (IN) was calculated as $\mathrm{IN}=\mathrm{ET}_{\mathrm{c}}-P_{\mathrm{e}}$, where $\mathrm{ET}_{\mathrm{C}}$ is the crop evapotranspiration and $P_{\mathrm{e}}$ the effective precipitation (75\% of $P$ recorded by the weather station in the orchard). Daily $\mathrm{ET}_{\mathrm{c}}$ values were calculated as $\mathrm{ET}_{\mathrm{c}}=K_{\mathrm{c}} K_{\mathrm{r}} \mathrm{ET}_{\mathrm{o}}$, where $K_{\mathrm{c}}$ is the crop coefficient and $K_{\mathrm{r}}$ is a coefficient related to the percentage of ground covered by the crop. We used the $K_{\mathrm{c}}$ values derived by Fernández et al. (2006a) for an orchard of similar characteristics, with a slightly greater canopy volume than that of the present orchard (0.76 in May; 0.70 in June; 0.63 in July and August; 0.72 in September; 0.77 in October; 1.07 in November) and we calculated a $K_{\mathrm{r}}$ value of 0.75 after Fereres and Castel (1981). Daily values of the FAO-56 Penman-Monteith $\mathrm{ET}_{\mathrm{o}}$ were collected from a nearby standard weather station belonging to the Agroclimatic Information Network of the Junta of Andalusia. Water for irrigation was supplied by a system consisting of one drip line per tree row with a $2 \mathrm{~L} \mathrm{~h}^{-1}$ dripper every $0.5 \mathrm{~m}$ with, and one caudalimeter per treatment to record the applied IAs. We used an irrigation controller (Agronic 2000, Sistemes Electrònics PROGRÉS, S.A., Lleida, Spain) for supplying the calculated INs. From June 7 to June 13, all trees in the orchard received enough water to match the crop water requirements. From June 14, day of year (DOY) 165, to October 24 (DOY 297), the 30RDI treatment was imposed in the orchard. All trees were fertilized by injecting a $8 \mathrm{~N}-3 \mathrm{P}-8 \mathrm{~K}+0.05 \% \mathrm{~B}+0.05 \%$ Fe solution into the irrigation system, once a week throughout the irrigation season. The amounts of fertilizers were enough to cover the tree requirements.

\subsection{Root and leaf area measurements}

To study root distributions, two soil trenches $1.5 \mathrm{~m}$ wide, $1.5 \mathrm{~m}$ deep and $3.5 \mathrm{~m}$ long were opened in July 2011, one in the Control treatment and one in the 30RDI treatment. Trenches were dug with a backhoe, and then the faces were squared and smoothed with a shovel. Using a $1 \mathrm{~m} \times 1 \mathrm{~m}$ grid fixed on the trench face with nails, intersection root density (number of intersections per unit area) was counted in each grid unit of the trench wall face. A water spray bottle was used to highlight the roots to facilitate the identification of root ends. After counting all roots, a total of 17 soil samples with size $200 \mathrm{~cm}^{3}$ were removed by soil coring. Samples were transferred to the laboratory, where roots were washed from the soil samples and analyzed. All the roots were scanned with a WinRhizo LA 1600 scanner with a resolution of 300 dots per inch, and analyzed with the WinRhizo software (Régent Instruments, Quebec, Canada). Distribution of roots diameters and root length were measured. Root length density (RLD) was calculated from root length and soil volume sampled.

Leaf area $\left(A_{\mathrm{L}}\right)$ was measured in each plot on the same days that the water status of the trees was monitored, i.e., once every two weeks during the irrigation season. Measurements were made at dawn with a LAI-2200 Plant Canopy Analyzer (Li-Cor, Inc., Lincoln, NE, USA). We followed the measurement strategy proposed by Villalobos et al. (1995) for olive orchards. Briefly, eight points per plot were measured in each of the four plots per treatment. In each plot, four points were measured just underneath the tree row, where $\mathrm{LAI}$ is maximum $\left(\mathrm{LAI}_{\max }\right)$, and other four points were measured in the midpoint between two rows where LAI is minimum $\left(\mathrm{LAI}_{\min }\right)$. The average $\mathrm{LAI}\left(\mathrm{LAI}_{\mathrm{avg}}\right)$ was calculated using the fraction of ground cover $(\mathrm{GC})$ as a weighting factor $\left(\mathrm{LAI}_{\mathrm{avg}}=\mathrm{LAI}_{\max }\right.$ $\mathrm{GC}+\mathrm{LAI}_{\text {min }}(1-\mathrm{GC})$ ). The average tree $A_{\mathrm{L}}$ was calculated as $\mathrm{LAI}_{\mathrm{avg}}$ multiplied by the ground area per plot and dividing by the number of trees in the plot.

\subsection{Soil water status and physical properties}

In every plot we installed two access tubes for a Profile probe (Delta-T Devices Ltd., Cambridge, UK) at $0.5 \mathrm{~m}$ from the tree trunk and $0.1 \mathrm{~m}$ and $0.4 \mathrm{~m}$, respectively, from the nearest dripper. Measurements of volumetric soil water content $\left(\theta, \mathrm{m}^{3} \mathrm{~m}^{-3}\right)$ in each access tube were made 1-2 times per week, at 0.1, 0.2, 0.3, 0.4, 0.6 and $1.0 \mathrm{~m}$ depths. The Profile probe was calibrated in situ, by comparing the values derived from the Profile probe readings with 
$\theta$ values measured with TDR probes (TDR FOM/mts, Institute of Agrophysics, Lubin, Poland).

Cores of undisturbed soil were extracted from 0.1 to $1.0 \mathrm{~m}$ depth in cylinders $(2.5 \mathrm{~cm}$ long and $5 \mathrm{~cm}$ diameter) to determine textural characteristics and dry bulk soil density $(\rho)$. Two contrasted soil layers were identified. This soil has a $0.6 \mathrm{~m}$ deep top layer with an average textural composition of $77.7 \%$ sand, $2.2 \%$ silt and $20.1 \%$ clay, and $\rho=1.73 \mathrm{~kg} \mathrm{~m}^{-3}$. Below $0.6 \mathrm{~m}$ there is a less porous soil layer with average textural values of $60.9 \%$ sand, $2.0 \%$ silt and $37.1 \%$ clay, and $\rho=1.82 \mathrm{~kg} \mathrm{~m}^{-3}$. Undisturbed soil cores were used to determine $\theta$ at $-0.033 \mathrm{MPa}$ using a $0.1-\mathrm{MPa}$ porous ceramic pressure plate (Soil Moisture Equipment Corp., Santa Barbara, CA, USA) and $-1.5 \mathrm{MPa}$ by using a 1.5-MPa porous ceramic pressure plates with compressed air (Soil Moisture Equipment Corp., Santa Barbara, CA, USA). Values of residual $\theta\left(\theta_{\text {resid }}\right)$, saturated $\theta\left(\theta_{\text {sat }}\right)$, retention curve parameters $(\alpha, n)$ and soil hydraulic conductivity at saturation $\left(K_{\text {sat }}\right)$ were estimated by using the Rosetta model (Schaap et al., 2001). $\alpha$ is related to the inverse of the air entry suction and $n$ is a measure of the pore-size distribution. Rosetta model is based on van Genuchten model. Inputs to Rosetta were textural characteristics, $\rho$, and $\theta$ at $-0.033 \mathrm{MPa}$ and $-1.5 \mathrm{MPa}$.

\subsection{Plant water status}

The time course of tree water status was monitored by measuring the leaf water potential at predawn $\left(\Psi_{\text {pd }}\right)$ and midday $\left(\Psi_{1}\right)$, and the midday stem water potential ( $\left.\Psi_{\text {stem }}\right)$, once every two weeks during the whole irrigation season. Measurements were made with a Scholander-type pressure chamber (PMS Instrument Company, Albany, Oregon, USA) on one leaf per tree from two representative trees per plot $(n=8)$. For $\Psi_{\mathrm{pd}}$ and $\Psi_{1}$ we sampled the 4 th or 5 th leaf below the apex of peripheral twigs at about $1.5-1.9 \mathrm{~m}$ above ground. They were healthy, fully developed, sun-exposed leaves facing east. For $\Psi_{\text {stem }}$ we sampled leaves from the inner part of the canopy. These leaves were wrapped in aluminum foil ca. $2 \mathrm{~h}$ before the measurements to ensure hydraulic equilibration with stem xylem water.

Osmotic potential ( $\pi$ ) was measured on the same days as $\Psi_{1}$. At dawn, five leaves per plot were sampled, cleaned with a damp paper towel, packed in aluminum foil and immediately frozen in liquid nitrogen. These leaves were stored in a freezer until analysis. The expressed sap from each leaf was extracted according to Callister et al. (2006). $\pi$ was then determined with a thermocouple psychrometer with six standard C-52 sample chambers (Wescor Inc., Logan, UT, USA) connected to a datalogger (PSYPRO, Wescor Inc.). The measurements were carried out under constant temperature conditions. For each sample, one paper disc soaked with $10 \mu \mathrm{l}$ of the expressed sap was loaded into the sample chamber. A waiting time of 15 min was determined for sample equilibrium.

\subsection{Xylem vulnerability}

Xylem vulnerability was studied in current year olive shoots. The vulnerability to xylem cavitation was determined by the benchtop technique (Tyree and Dixon, 1986; Sperry and Tyree, 1988). Briefly, 1.5-m-long branches were sampled under water from different representative olive trees, wrapped in plastic bags with wet paper towel inside to prevent water loss and transported to the lab where they were left to dry out on the bench. During the drying process, repeated measurements of xylem water potential and percentage loss of conductivity (PLC) were made. For PLC measurement, 30-mm-long segments were sampled under water from the current-year shoots of the collected branches and connected to a XYLǐEM apparatus (Bronkhorst, Montigny les Cormeilles, France) for determining their hydraulic conductivity $(K)$. $K$ was determined with a filtered $(0.22 \mu \mathrm{m}) 50 \mathrm{mM} \mathrm{KCl}$ solution at $3 \mathrm{kPa}$ until a steady-stated $K$ was attained. Segments were then flushed at $150 \mathrm{kPa}$ for $20 \mathrm{~min}$ to remove the embolisms and $K$ measured again for determining the maximum $K\left(K_{\mathrm{m}}\right)$. The PLC was then calculated as

$\mathrm{PLC}=100 \times\left(1-\frac{K}{K_{\mathrm{m}}}\right)$

\subsection{Leaf gas exchange and sap flow}

Measurements of stomatal conductance $\left(g_{s}\right)$ were made with a Li-6400 open flow single pass gas exchange system using a standard $2 \mathrm{~cm} \times 3 \mathrm{~cm}$ leaf chamber (Li-Cor Inc., Lincoln, NE, USA) at the hours of maximum stomatal conductance, from ca. 08.00 to 09.00 GMT. For these measurements, two healthy, fully developed, sunexposed leaves per tree and treatment were sampled (8 leaves per treatment). Chamber conditions were set to match ambient conditions of $\mathrm{CO}_{2}$ concentration, radiation and temperature.

On April 14 we installed heat-pulse velocity (HPV) probes (Tranzflo NZ Ltd., Palmerston North, New Zealand) for sap flow measurements by the $T_{z}$ heat-pulse method (Green et al., 2003). One representative tree per plot was instrumented in three plots per treatment (30RDI and control). Two sets of probes were installed into the trunk of each tree. Each set had two temperature probes, located at $5 \mathrm{~mm}$ upstream and $10 \mathrm{~mm}$ downstream of a linear heater probe. Each temperature probe had four thermocouples, at 5, 12, 22 and $35 \mathrm{~mm}$ below the cambium. One set of HPV probes faced east and the other west, and the minimum distance between the two sets was approximately $0.1 \mathrm{~m}$. Heat pulses (60 J; $60 \mathrm{~W}$ over $1 \mathrm{~s}$ ) were applied once every $30 \mathrm{~min}$. Both the firing of the heat pulses and the recording of the outputs from the probes were made by a CR10X Campbell datalogger (Campbell Scientific Inc., North Logan, USA). The system worked continuously from April 27 to October 30, 2011.

The method was validated for olive by Fernández et al. (2006b). We followed their procedure for processing the HPV outputs. The resulting values of each set of probes were averaged to derive the sap flux in the trunk $\left(Q, \mathrm{Lh}^{-1}\right)$, as well as the plant water consumption per leaf area $\left(E_{\mathrm{p}}, \mathrm{mmol} \mathrm{m}^{-2} \mathrm{~s}^{-1}\right)$.

Canopy conductance $\left(g_{\mathrm{c}}\right)$ was estimated from $E_{\mathrm{p}}$ and air vapor pressure deficit (VPD), assuming a complete coupling between canopy and atmosphere (Jarvis and McNaughton, 1986; Moreno et al., 1996), as

$g_{\mathrm{c}}=\frac{E_{\mathrm{p}}}{\mathrm{VPD}}$

The hydraulic resistance of the plant $\left(R_{\mathrm{p}}\right)$ was calculated as

$R_{\mathrm{p}}=\frac{\Delta \psi}{E_{\mathrm{p}}}$

where $\Delta \Psi$ is the difference between $\Psi_{1}$ and $\Psi_{\mathrm{pd}}$.

\subsection{SACC model}

The SACC model (Sperry et al., 1998) is based on the biophysics of water flow through the porous media of soil and xylem. A comprehensive overview of the model can be found in Sperry et al. $(1998,2002)$. A brief description is provided here. Water flow rate through vegetation $\left(E_{\mathrm{p}}\right)$ is predictable from the hydraulic conductance of the media $(K[\Psi])$ and the difference between the soil water potential of the rooting zone $\left(\Psi_{\mathrm{sr}}\right)$ and the xylem pressure in the plant canopy $\left(\Psi_{\mathrm{pc}}\right)$ :

$E_{\mathrm{p}}=K(\psi)\left(\psi_{\mathrm{sr}}-\psi_{\mathrm{pc}}\right)$

The hydraulic conductance is a declining function of $\Psi$ as a result of soil drying and xylem cavitation. The $K(\Psi)$ function for soil is 


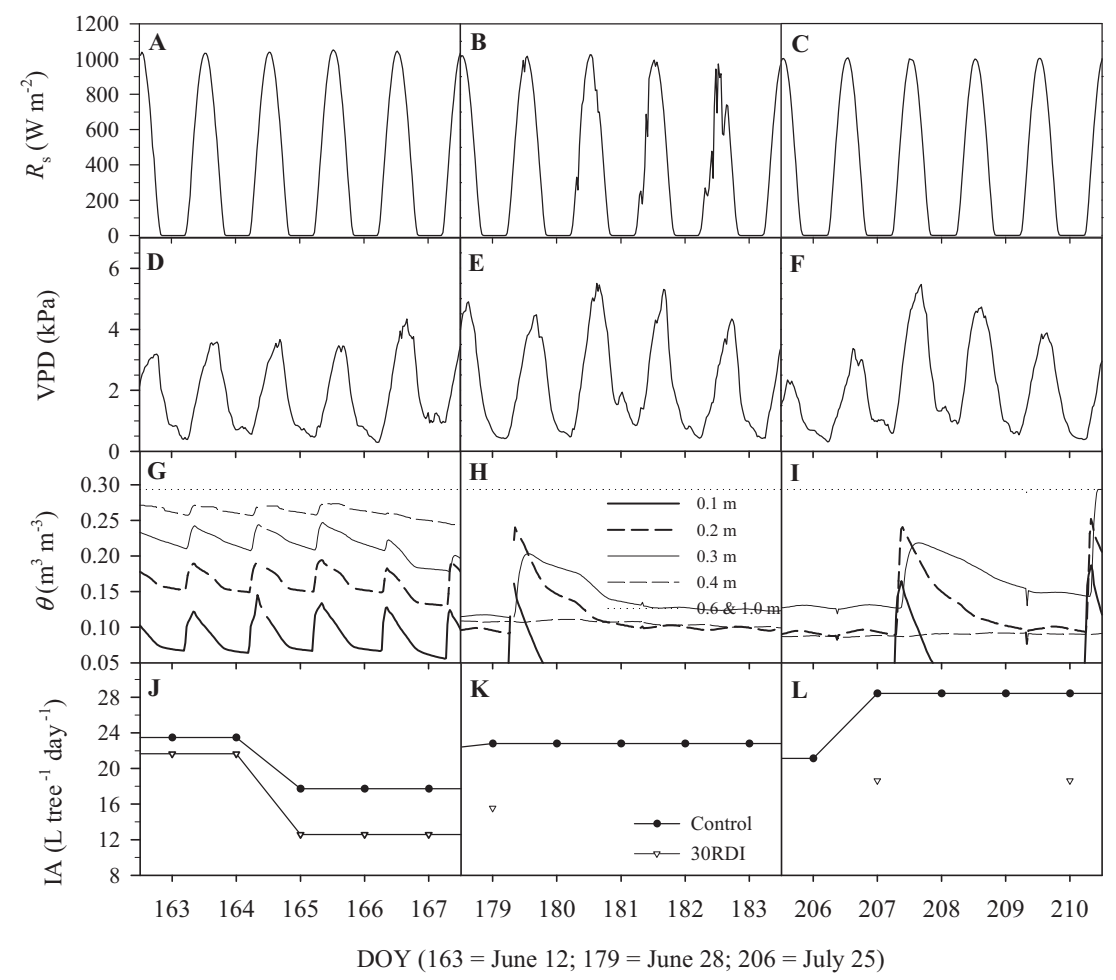

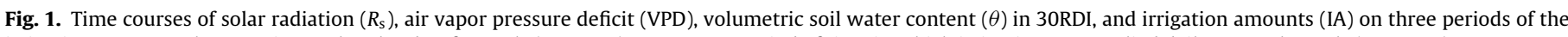

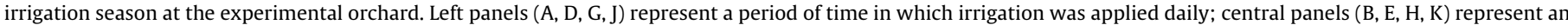

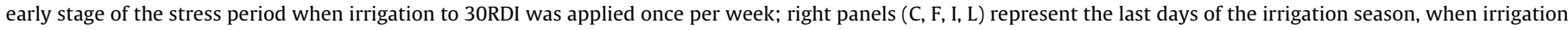
to 30RDI turned into twice per week. DOY = day of year.

well characterized for soil types (Campbell, 1985), and the $\Psi$ gradient across the rhizosphere is assessed from the ratio of absorbing root area per leaf area $\left(A_{\mathrm{R}}: A_{\mathrm{L}}\right)$. The $K(\Psi)$ function of xylem is the "vulnerability curve" which can be measured on stems and roots (Alder et al., 1996). The SACC model solves for $E_{\mathrm{p}}$ as a function of rooting depth, profile of $\Psi_{\mathrm{s}}$, vulnerability curves, and $\Psi_{\mathrm{pc}}$ (Sperry et al., 1998). The utility of the SACC model is to provide a mechanistic, predictable, and species-specific link between $\Psi_{\mathrm{sr}}$ and $g_{\mathrm{c}}$. The link is chiefly influenced by the rooting profile and the vulnerability curve: species that are resistant to cavitation or that tap reliable soil water respond with less sensitivity to soil drought than vulnerable or shallow-rooted species. However, the model also predicts the critical fluxes and pressures at hydraulic failure where the soil-plant hydraulic continuum is severed by dynamic water stress (Sperry et al., 1998). In this study we focus on this last application of the model.

\subsection{BMF model}

The BMF model (Buckley et al., 2003) is based on the observed dependence of stomatal aperture on turgor pressures of stomatal guard cells and adjacent epidermal cells, and on the effect of stomatal transpiration on those turgor pressures, via bulk leaf water potential. The model assumes that guard cell osmotic pressure is actively regulated to seek a "target" value that is proportional to both epidermal turgor pressure and the concentration of ATP in photosynthesizing cells $(\tau) . \tau$ is a function of irradiance, intercellular $\mathrm{CO}_{2}$ concentration and photosynthetic, as discussed below. Additional parameters in the model include soil water potential $\left(\Psi_{\mathrm{S}}\right)$, leaf osmotic pressure $(\pi)$, plant hydraulic resistance $(R)$, VPD, net epidermal mechanical advantage $(M)$, a scaling factor that includes effects of stomatal density $(\chi)$ and a parameter that describes sensitivity to epidermal turgor and ATP concentration $(\beta)$. The model predicts stomatal conductance $\left(g_{s}\right)$ as

$g_{\mathrm{s}}=\frac{\chi(\beta \tau-M)\left(\Psi_{\mathrm{s}}+\pi\right)}{1+\chi(\beta \tau-M) \mathrm{RVPD}}$

Preliminary work showed that qualitative predictions of $g_{\mathrm{s}}$ were insensitive to the value of $M$, a parameter that is very difficult to measure, so for simplicity we set $M=0$. This further allowed the product $\chi \beta$ to be treated as a single parameter. Parameters in the model were either measured as described above $\left(\Psi_{s}, \pi\right.$, and VPD), fitted by least-squares ( $\chi \beta$ and $R$ ), or simulated $(\tau)$. The concentration of ATP $(\tau)$ was calculated using the model of Farquhar and Wong (1984), which is based on the photosynthesis model of Farquhar et al. (1980). Parameters of the Farquhar et al. model specific for olive were measured by gas exchange, as described by Diaz-Espejo et al. (2006). The model for ATP $(\tau)$ predicts a roughly hyperbolic increase of $\tau$ with increasing irradiance, and a negative response of $\tau$ to intercellular $\mathrm{CO}_{2}$ concentration that is steeper at high light, consistent with laboratory studies of stomatal responses to light and $\mathrm{CO}_{2}$ (e.g., Buckley et al., 2003; Messinger et al., 2006). Buckley et al. (2003) discussed in detail the rationale for using this model, and its implications for predicting stomatal responses to light and $\mathrm{CO}_{2}$.

\section{Results}

\subsection{Meteorological and soil data}

Fig. 1 shows the time courses of main environmental variables and IAs for three different periods of the olive growing season. Left panels (Fig. 1A, D, G, J) represent the period in which irrigation was supplied daily in both treatments, although with lower IAs in 30RDI. In the central panels (Fig. 1B, E, H, K), irrigation in 30RDI 
Table 1

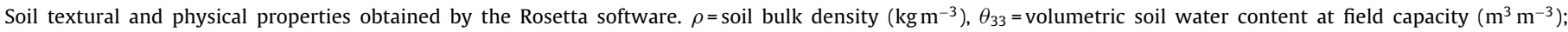

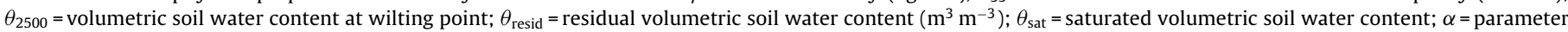
related to the inverse of the air entry suction $\left(\mathrm{cm}^{-1}\right) ; n=$ parameter related to the pore-size distribution (unitless); $K_{\mathrm{s}}=$ saturated hydraulic conductivity ( $\mathrm{cm} \mathrm{day}^{-1}$ ).

\begin{tabular}{|c|c|c|c|c|c|c|c|c|c|c|c|}
\hline Depth & Sand & Clay & Silt & $\rho$ & $\theta_{33}$ & $\theta_{2500}$ & $\theta_{\text {resid }}$ & $\theta_{\text {sat }}$ & $\log _{10}(\alpha)$ & $\log _{10}(n)$ & $\log _{10}\left(K_{\mathrm{s}}\right)$ \\
\hline 0-0.6 & 77.7 & 20.1 & 2.2 & 1.73 & 0.16 & 0.09 & 0.038 & 0.34 & -1.53 & 0.123 & 1.68 \\
\hline $0.6-1.0$ & 60.9 & 37.1 & 2 & 1.82 & 0.24 & 0.14 & 0.041 & 0.33 & -1.61 & 0.119 & 1.86 \\
\hline
\end{tabular}

was reduced to once per week, meanwhile in Control it continued in a daily basis. In the last period showed by the right panels (Fig. 1C, F, I, L) irrigation frequency to 30RDI was increased to twice per week. $\theta$ values in 30RDI echoed the irrigation events (Fig. 1G-I). During the first period water supply was enough to keep $\theta$ at nearly constant values, which increased with depth. However, the amplitude of their fluctuations decreased with depth (Fig. 1G). During the other periods, irrigation events affected the first $0.3 \mathrm{~m}$ of soil only. At $0.4 \mathrm{~m} \theta$ remained close to $0.1 \mathrm{~m}^{3} \mathrm{~m}^{-3}$. No changes were detected at $0.6 \mathrm{~m}$ and $1.0 \mathrm{~m}$ depth, where $\theta$ was close to saturation all along the season. Table 1 shows the textural characteristics in the soil orchard, defining a sandy loam soil layer for the first $0.6 \mathrm{~m}$, and then a sandy clay layer around 0.6 and downwards. Despite the large percentage of sand in both layers, the small differences in clay content produced large differences in their hydraulics properties. During most of the irrigation season, the radiation regime showed a constant pattern along the periods reaching maximum daily values of $1000 \mathrm{~W} \mathrm{~m}^{-2}$, with seldom exceptions of partially cloudy days (Fig. $1 \mathrm{~A}-\mathrm{C}$ ). Daily maximum VPD was always higher than $2 \mathrm{kPa}$ (Fig. 1D-F), and most frequently close to $5 \mathrm{kPa}$, with peak values close to $6 \mathrm{kPa}$. Air temperature reached maximum values of $39^{\circ} \mathrm{C}$.

\subsection{Roots distribution and leaf area}

A linear correlation was found between RLD and intersection root density on the trench walls. The slope was 2.47 after the intercept was forced to pass through zero. Root distribution observed on trench walls followed a pattern related to irrigation wet bulb locations in both Control and 30RDI treatments (Fig. 2). No roots were found below $0.45 \mathrm{~m}$. Root length density measured in soil core samplings reached a maximum value of $1.4 \mathrm{~cm} \mathrm{~cm}^{-3}$ in points inside wet bulbs. Wet bulbs were observed to have a volume of ca. $0.04 \mathrm{~m}^{3}$. Since each tree had three drippers, the total volume of wet soil was $0.12 \mathrm{~m}^{3}$. Assuming a radius for the fine roots of $0.25 \mathrm{~mm}$, an average $2.65 \mathrm{~m}^{2}$ of root area $\left(A_{\mathrm{R}}\right)$ was calculated. The distribution of roots shown in Fig. 3 helped us to determine the effective

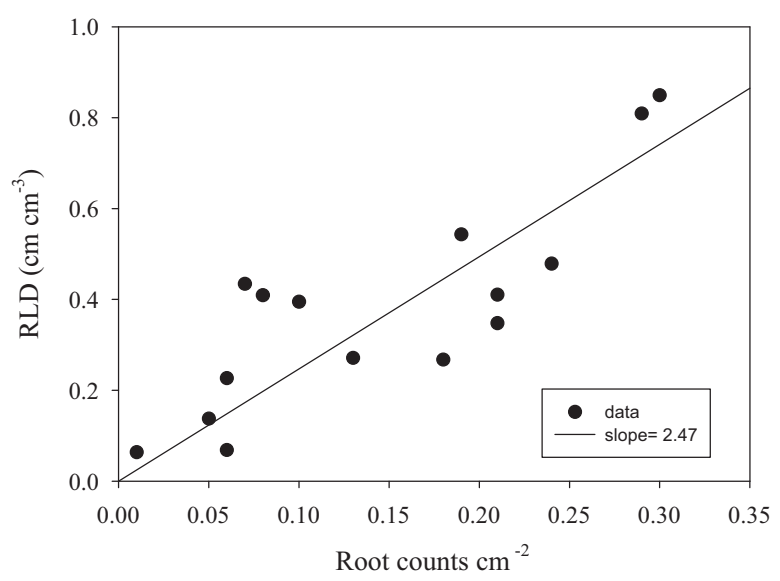

Fig. 2. Relationship between root length density (RLD) and root intersection on the trench wall per unit of surface. Data correspond to both control and 30RDI treatments. $r^{2}=0.65$ was significant at a value of $P<0.01$. depth of available water for the trees. The value of $0.45 \mathrm{~m}$ matched well with the seasonal evolution of $\theta$ at $0.4 \mathrm{~m}$ (and above) and at $0.6 \mathrm{~m}$ (and below) showed in Fig. 1G-I. Another evidence for the absence of roots below $0.45 \mathrm{~m}$ can be inferred from the constant value of $\theta$, close to saturation, measured all along the season. This value did not decrease even when $\theta$ at $0.4 \mathrm{~m}$ presented values as low as $0.12 \mathrm{~m}^{3} \mathrm{~m}^{-3}$. An upper limit of $0.1 \mathrm{~m}$ was also set on the view of the low values measured at this shallow depth, close to residual. Values of $\theta$ were turned into $\Psi_{s}$ by using soil physical parameters shown in Table 1 . A single value of $\Psi_{\mathrm{s}}$ was obtained from the integration of $\theta$ from 0.2 to $0.4 \mathrm{~m}$, and compared to the values of $\Psi_{\mathrm{pd}}$ measured in those trees, obtaining a good agreement.

Despite significant differences of $A_{\mathrm{L}}$ between treatments at the beginning of the growing season, the high growing rate of 30RDI trees during spring allowed them to catch up Control trees by the time the daily irrigation was still on (Fig. 4). At this time of the year $A_{\mathrm{L}}$ was on average $7.25 \mathrm{~m}^{2}$ per tree, meaning a LAI in the orchard of 1.43. However, Control trees grew again from mid July, up to maximum value of $12.3 \mathrm{~m}^{2}$ in October. This growing period was not observed in the 30RDI trees, which showed a constant $A_{\mathrm{L}}$ all over the studied period. Assuming no changes in $A_{\mathrm{R}}$ in 30RDI during this period, $A_{\mathrm{R}}: A_{\mathrm{L}}$ was calculated as 0.38 .
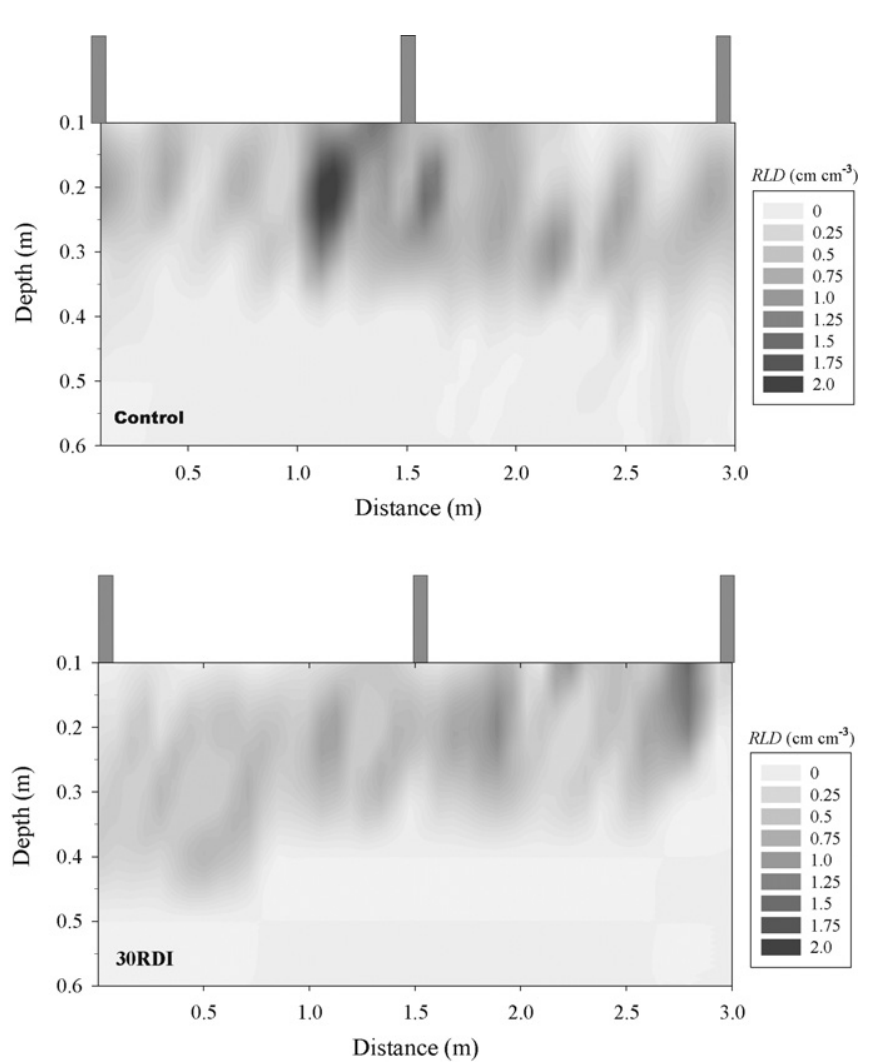

Fig. 3. Spatial distribution of root length density (RLD) on a trench wall in both the control and 30RDI treatment. RLD values were calculated from the relationship shown in Fig. 2. Vertical bars on the upper horizontal line represent the tree trunks. 
Table 2

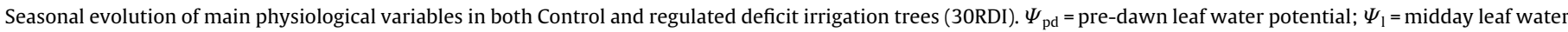

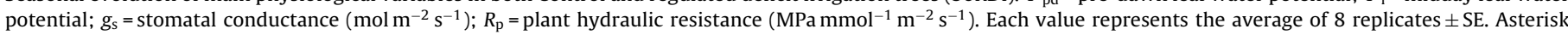
indicates significant differences between treatments on each date ( $t$-Student, $P<0.05$ ).

\begin{tabular}{|c|c|c|c|c|c|}
\hline \multirow[t]{2}{*}{ Variable } & \multirow[t]{2}{*}{ Treatment } & \multicolumn{4}{|l|}{ DOY } \\
\hline & & 165 & 181 & 209 & 223 \\
\hline \multirow[t]{2}{*}{$\Psi_{\mathrm{pd}}$} & Control & $-0.20(0.04)$ & $-0.31(0.05)^{*}$ & $-0.37(0.02)^{*}$ & $-0.30(0.03)^{*}$ \\
\hline & 30RDI & $-0.15(0.03)$ & $-0.50(0.03)^{*}$ & $-1.53(0.15)^{*}$ & $-1.09(0.11)^{*}$ \\
\hline \multirow[t]{2}{*}{$\Psi_{1}$} & Control & $-0.99(0.14)$ & $-1.33(0.13)$ & $-1.37(0.19)^{*}$ & $-1.07(0.12)^{*}$ \\
\hline & 30RDI & $-0.77(0.14)$ & $-1.80(0.23)$ & $-2.96(0.10)^{*}$ & $-2.50(0.19)^{*}$ \\
\hline \multirow[t]{2}{*}{$g_{s}$} & Control & $0.222(0.014)$ & $0.193(0.012)^{*}$ & $0.215(0.016)^{*}$ & $0.229(0.017)^{*}$ \\
\hline & 30RDI & $0.233(0.014)$ & $0.098(0.009)^{*}$ & $0.069(0.006)^{*}$ & $0.069(0.011)^{*}$ \\
\hline \multirow[t]{2}{*}{$R_{\mathrm{p}}$} & Control & $0.53(0.12)$ & $0.59(0.08)^{*}$ & $0.64(0.12)^{*}$ & $0.74(0.12)^{*}$ \\
\hline & 30RDI & $0.47(0.10)$ & $2.03(0.37)^{*}$ & $4.49(0.82)^{*}$ & $4.10(0.57)^{*}$ \\
\hline
\end{tabular}

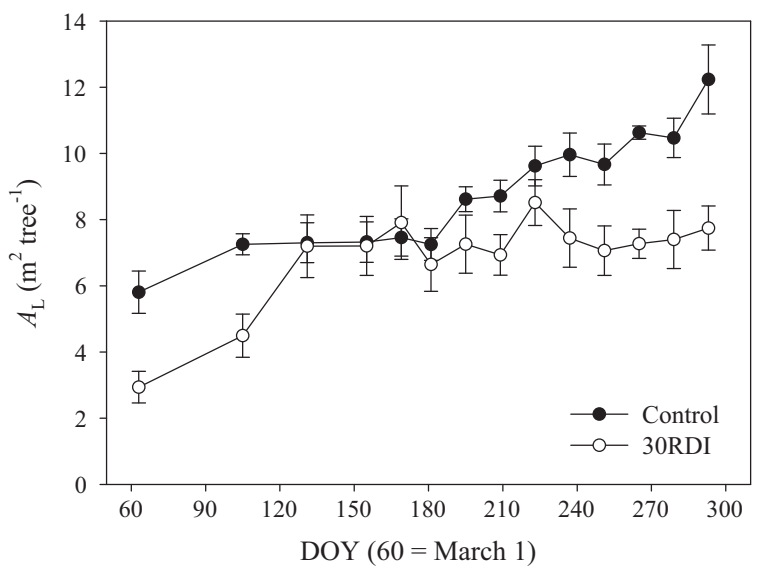

Fig. 4. Seasonal courses of tree leaf area $\left(A_{\mathrm{L}}\right)$ for the two irrigation treatments. DOY = day of year.

\subsection{Plant water status, leaf gas exchange and transpiration}

Full water availability in the soil for the Control trees was indirectly assessed on the view of the high values of $\Psi_{\text {pd }}$ measured along the growing season (Table 2). However, 30RDI trees presented a minimum value of $-1.5 \mathrm{MPa}$ on DOY 209. Proportionally,
$\Psi_{1}$ showed a clear difference between treatments as soon as the irrigation frequency changed to once or twice per week in 30RDI, getting to a minimum value of $-2.96 \mathrm{MPa}$ on July 28, DOY 209 (Table 2 ). At the same time, $g_{\mathrm{s}}$ showed nearly constant maximum values in Control trees along the season, meanwhile more than 3fold lower $g_{s}$ values were measured in 30RDI trees at the end of the studied period (Table 2 ). These data matched well with $E_{\mathrm{p}}$ estimated from sap flow, shown in Fig. 5. This figure shows a period in which irrigation was applied daily to both treatments, although with slightly lower IAs to 30RDI, and the period in which the maximum stress was observed. During the first period, very close $E_{\mathrm{p}}$ were measured in both treatments, the small differences reflecting likely the different IAs mentioned above. However, a clear drop of more than 5-fold in 30RDI was observed during the second period plotted. In this period the $E_{\mathrm{p}}$ cycles of stress and recovery following irrigation were clear. $R_{\mathrm{p}}$ increased in both treatments during summer (Table 2). However, in Control trees $R_{\mathrm{p}}$ increased 1.4 -fold, while in 30RDI trees the increase was over 8-fold.

\subsection{SACC model}

Soil and plant hydraulic properties are the main determinants of the hydraulic limits for a species in a particular soil. Fig. 6A shows the relationship between $K_{\mathrm{s}}$ and $\Psi_{\mathrm{s}}$ based on the Van Genuchten equation. Despite of its high sand content, the orchard soil behaves

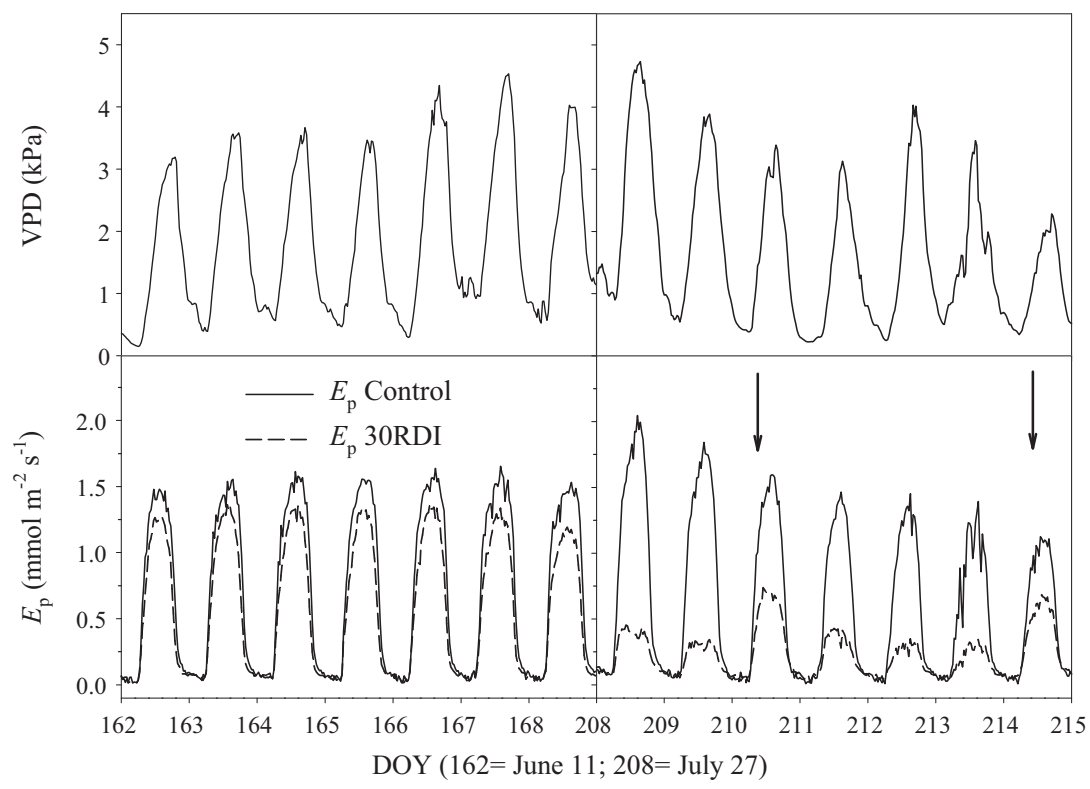

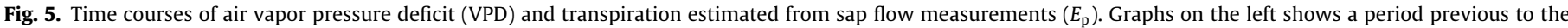

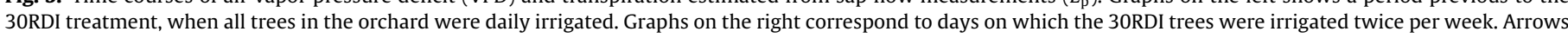
indicate irrigation events during this second period. DOY = day of year. 


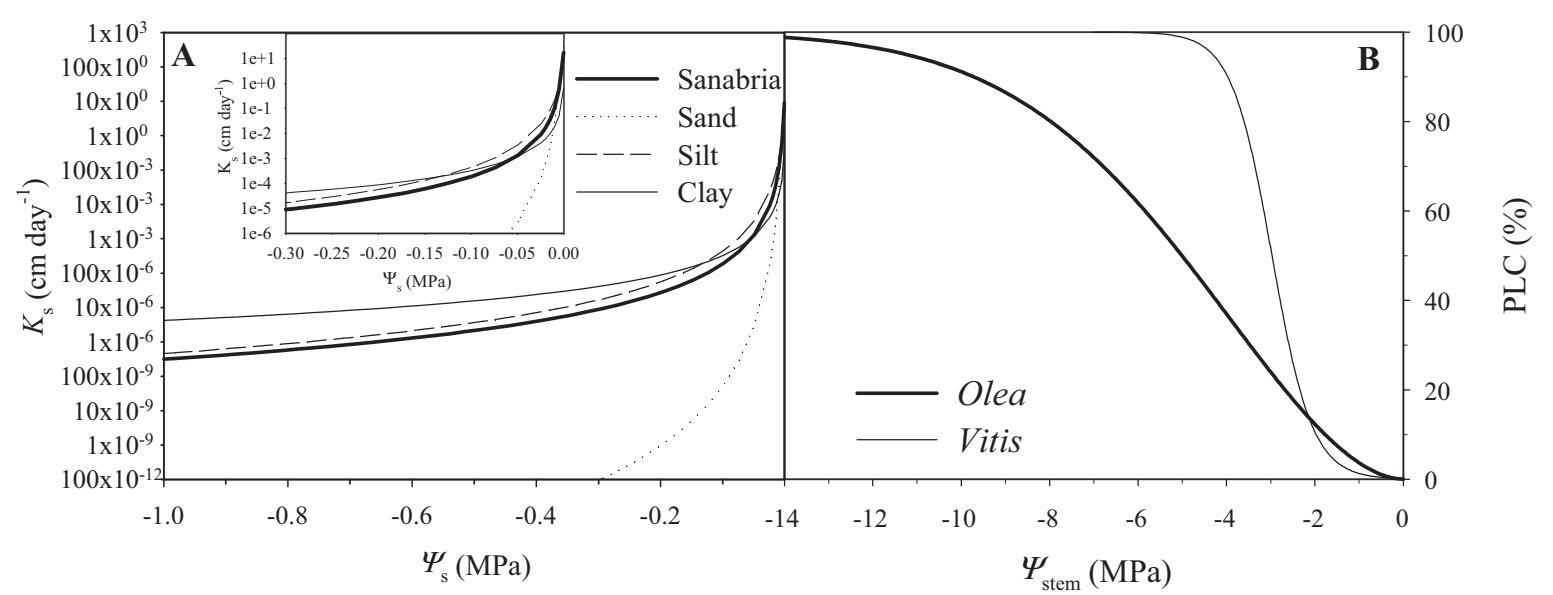

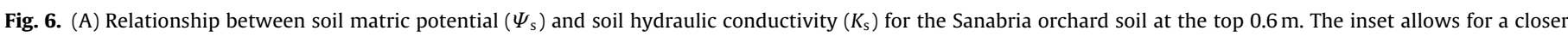

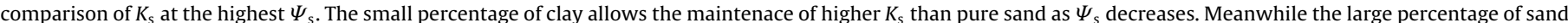

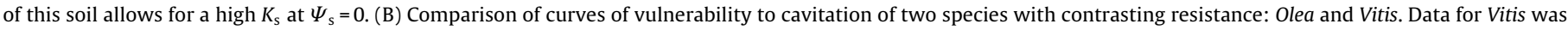
obtained from Choat et al. (2010). PLC data were fit with the Weibull equation: Olea, $d=6.13, c=1.81 ;$ Vitis, $d=2.97, c=2.2$.

more similar to a typical clay or silt soil, rather than a sandy soil. However, its high sand content makes it have 25-fold greater $K_{\mathrm{s}}$ than clay at $\Psi_{\mathrm{s}}=0 \mathrm{MPa}$, and 13 -fold smaller $K_{\mathrm{S}}$ at $\Psi_{\mathrm{s}}=-1.0 \mathrm{MPa}$. Xylem vulnerability curves (Fig. 6B) show that olive is quite resistant to embolism. A PLC of $24 \%$ was found at $\Psi_{\text {stem }}=-3.0 \mathrm{MPa}$, the minimum $\Psi_{\text {stem }}$ measured in the field site that year. The $\Psi_{\text {stem }}$ at which $50 \%$ of $K$ is lost $\left(\mathrm{P}_{50}\right)$ was $-5.0 \mathrm{MPa}$. A complete loss of $K\left(\mathrm{P}_{100}\right)$ was only achieved at values lower than $-15 \mathrm{MPa}$. By comparison, grapevine - another woody crop considered to be well-adapted to semi-arid conditions - showed a $\mathrm{P}_{50}$ of $-2.8 \mathrm{MPa}$, and a $\mathrm{P}_{100}$ around $-5 \mathrm{MPa}$.

This information, together with $A_{\mathrm{R}}$ and $A_{\mathrm{L}}$, was used to build the "envelope" of water use proposed by Sperry et al. (1998, 2002). The difference between the actual transpiration and the envelope is called the safety margin, and it is reduced as $\Psi_{\mathrm{s}}$ is lower. Fig. 7 shows four different envelopes: two for olive and two for grapevine. In addition, actual data of $E_{\mathrm{p}}$ vs $\Psi_{\mathrm{s}}$ were obtained from sap flow and continuous measurements of $\theta$ in the orchard and included in the plot for comparison. Data fit well under the olive envelope (thick

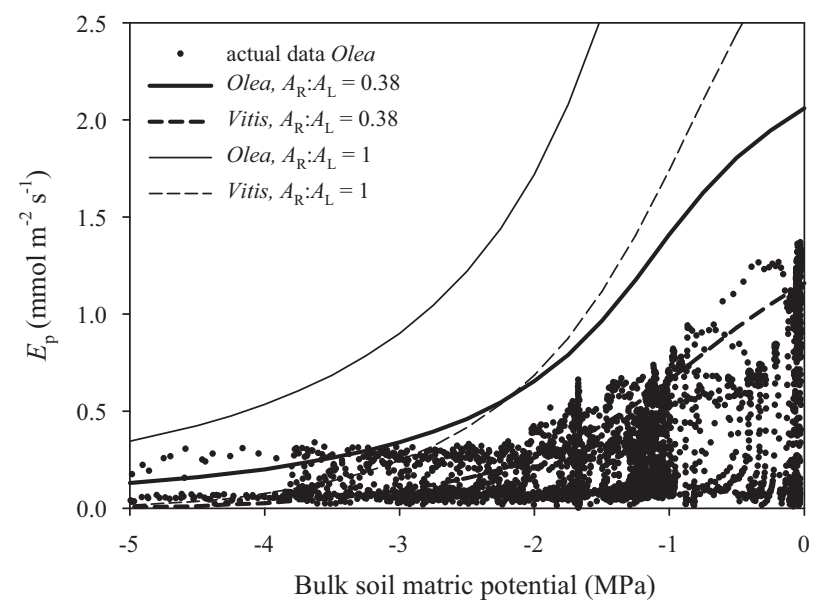

Fig. 7. Results of plant transpiration $\left(E_{\mathrm{p}}\right)$ simulated by the SACC model for two species of contrasting vulnerability to caviation: Olea, resistant, and Vitis, sensitive. All simulations were made for the soil conditions of our experimental orchard. Lines represent the hydraulic limit to transpiration fitted both by the rhizosphere and xylem. Simulations were made for two different root-leaf area ratios $\left(A_{\mathrm{R}}: A_{\mathrm{L}}\right)$. The lower $A_{\mathrm{R}}: A_{\mathrm{L}}$ value, 0.38 , is the actual value measured in the experimental orchard. Data points represent the actual $E_{\mathrm{p}}$ derived from sap flow measurements in the orchard. line) for most of the range of $\Psi_{s}$. For very low values of $\Psi_{s}$ data were above the limits. This could be due to uncertainty in $\Psi_{s}$ arising from integration over three layers of heterogeneous soil moisture. Alarge safety margin is evident between the envelope at $A_{\mathrm{R}}: A_{\mathrm{L}}$ measured in the orchard at high $\Psi_{\mathrm{s}}$. However, this margin is severely reduced at $\Psi_{\mathrm{S}}$ close to $-3 \mathrm{MPa}$. For grapevine, a similar value of $A_{\mathrm{R}}: A_{\mathrm{L}}$ reduces the envelope notably, indicating that grapevine could not sustain the $E_{\mathrm{p}}$ values measured for olive. A three-fold increase in $A_{\mathrm{R}}: A_{\mathrm{L}}$ increased the safety margin, emphasizing the differences in withinplant hydraulic limitation in the two species.

The model can be used to simulate the effect of pruning intensity (changing $A_{\mathrm{L}}$ ) or the impact of the number of drippers (changes in volume of wet soil and therefore $A_{\mathrm{R}}$ ) in $E_{\mathrm{p}}$. As expected, the increase in LAI decreases $E_{\mathrm{p}}$ (Fig. 8A), assuming that $A_{\mathrm{R}}$ keeps constant (through changes in RLD, since the volume of soil is limited). If LAI is doubled, maximum $E_{\mathrm{p}}$ is halved. An increase in the number of wet drippers from 3 to 5 would nearly compensate for an increase in LAI. Since each dripper generates a wet bulb in the soil of $0.3 \mathrm{~m}$ in diameter, and each tree is $1.5 \mathrm{~m}$ apart from neighbors, five drippers is the maximum number that a line can hold.

\subsection{BMF model}

$g_{c}$ values estimated from sap flow measurements are plotted in Fig. 9 for the days leaf gas exchange and leaf water potential were measured (Table 2). The use of $g_{c}$ values allowed us to have complete series of diurnal evolution of a close surrogate of $g_{s}$ to apply the model. On DOY 165 during the period of daily irrigation in 30RDI, no significant differences were observed between treatments. However, differences emerged as the soil dried out. A 4-fold decrease in 30RDI gc compared to Control gc values was observed on DOY 209. The model fit well to measured $g_{c}$ on all dates shown and in both treatments. The model was able to reproduce the two peaks measured on at the beginning of DOY 181. The seasonal evolution of the three parameters of the model is plotted in Fig. 10. $\pi$ was measured and input to the model. Fig. $10 \mathrm{~A}$ shows identical osmotic adjustment (change in $\pi$ with $\Psi_{\mathrm{s}}$ ) in both treatments despite their differences in $\Psi_{1}$. Tree hydraulics showed differences between treatments (Fig. 10B). These differences were evident from DOY 181, and especially later on, when a 3-fold increase in $R$ of 30RDI was estimated by the model (which was fitted by least squares). Control trees showed a nearly steady value of $R$ along the season. $\chi \beta$ (also fitted by least squares) showed a similar seasonal trend in both treatments (Fig. 10C), except on DOY 223 when 


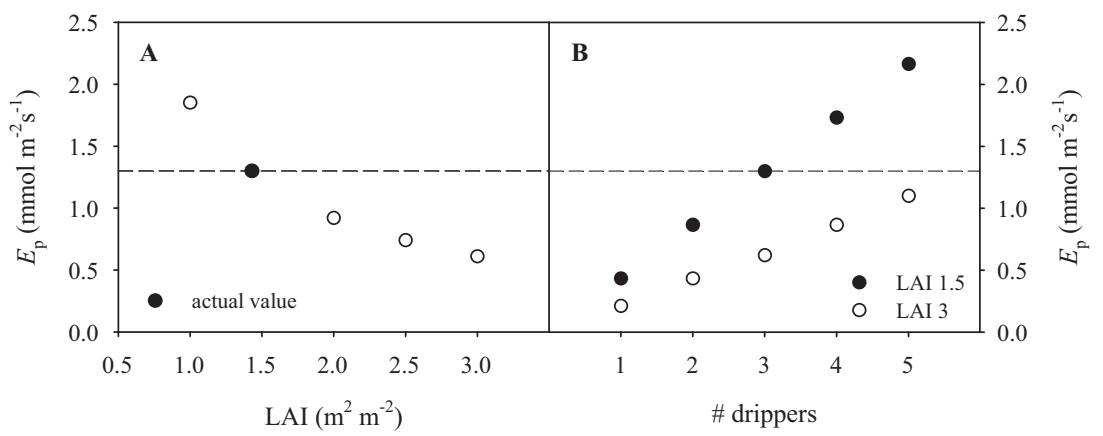

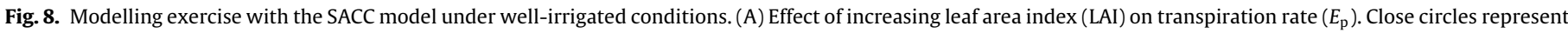

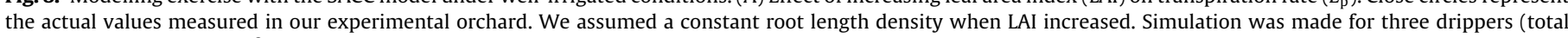

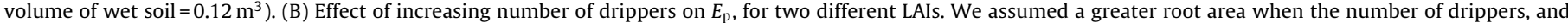
therefore the volume of wet soil, increased. It was assumed that root distribution followed the pattern shown in Fig. 3.

a small recovery was obtained in Control. The model always predicted higher values for Control than for 30RDI.

\section{Discussion}

The use of models with a mechanistic basis has a strong attraction for scientists working on the control of transpiration by plants under water stress conditions and on irrigation scheduling. There are numerous interacting processes involved in the acclimation of plants to water stress (Chaves et al., 2002; McDowell et al., 2008; Neumann, 2008). The integration of all the involved mechanisms is challenging, in particular the coordination of responses at different scales, from the stomata to the whole plant and their interaction with the soil. Mechanistic models help to describe the processes across the scales, including the soil and plant hydraulic resistance, and the leaf/tissue scale of stomatal regulation. The results obtained in this work are very encouraging for understanding and interpreting the behaviors usually observed in fruit woody plants during acclimation to drought. We have used process-based models to describe the main physiological changes observed in a hedgerow olive orchard under regulated deficit irrigation in southern Europe during an irrigation season, and to put these responses in the context of local climate and soil characteristics.

\subsection{Physiological response to water stress}

Transpiration was steady in both treatments during the first period, during which irrigation was applied daily, and despite wide variation in VPD. This indicates strong stomatal regulation (Fig. 5, left panel). Therefore, we can conclude that a maximum $E_{\mathrm{p}}$ of $1.7 \mathrm{mmol} \mathrm{m}^{-2} \mathrm{~s}^{-1}$ and $1.3 \mathrm{mmol} \mathrm{m}^{-2} \mathrm{~s}^{-1}$ are the limits for Control and 30RDI, respectively, at this time of the season. When the irrigation frequency decreased to once or twice per week in 30RDI (Fig. 5, right panel), $E_{\mathrm{p}}$ decreased and showed a cycle of recovery and down-regulation that agreed well with the irrigation events. Even on days when irrigation was applied, $E_{\mathrm{p}}$ did not fully recover. Moreover, on DOY 208 a maximum $E_{\mathrm{p}}$ of $2 \mathrm{mmol} \mathrm{m}^{-2} \mathrm{~s}^{-1}$ was achieved in Control, i.e., $17 \%$ higher than in the first period studied. Two questions arise from the observation of these data: (1) Why was the response of 30RDI trees to irrigation so dynamic in comparison to other findings reported for olive under deficit irrigation (DI) and even under dry-farming conditions (Fernández et al., 2008b)? and

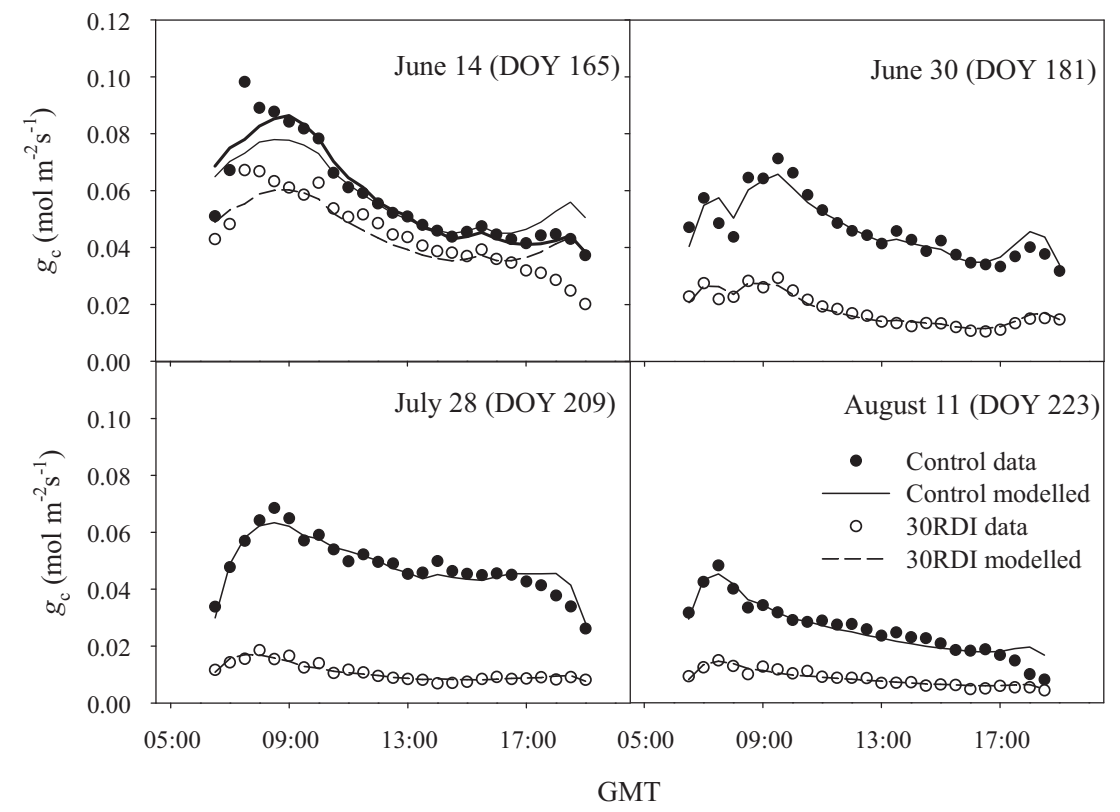

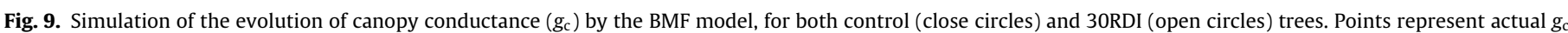

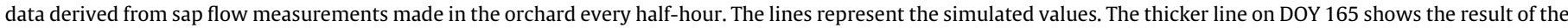

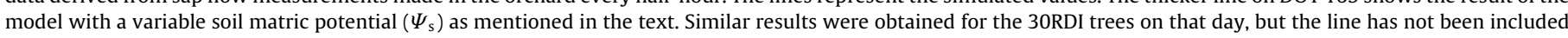
for clarity. The input meteorological data was obtained from the weather station located in the orchard, and $\Psi_{\mathrm{s}}$ was estimated from predawn leaf water potential. 


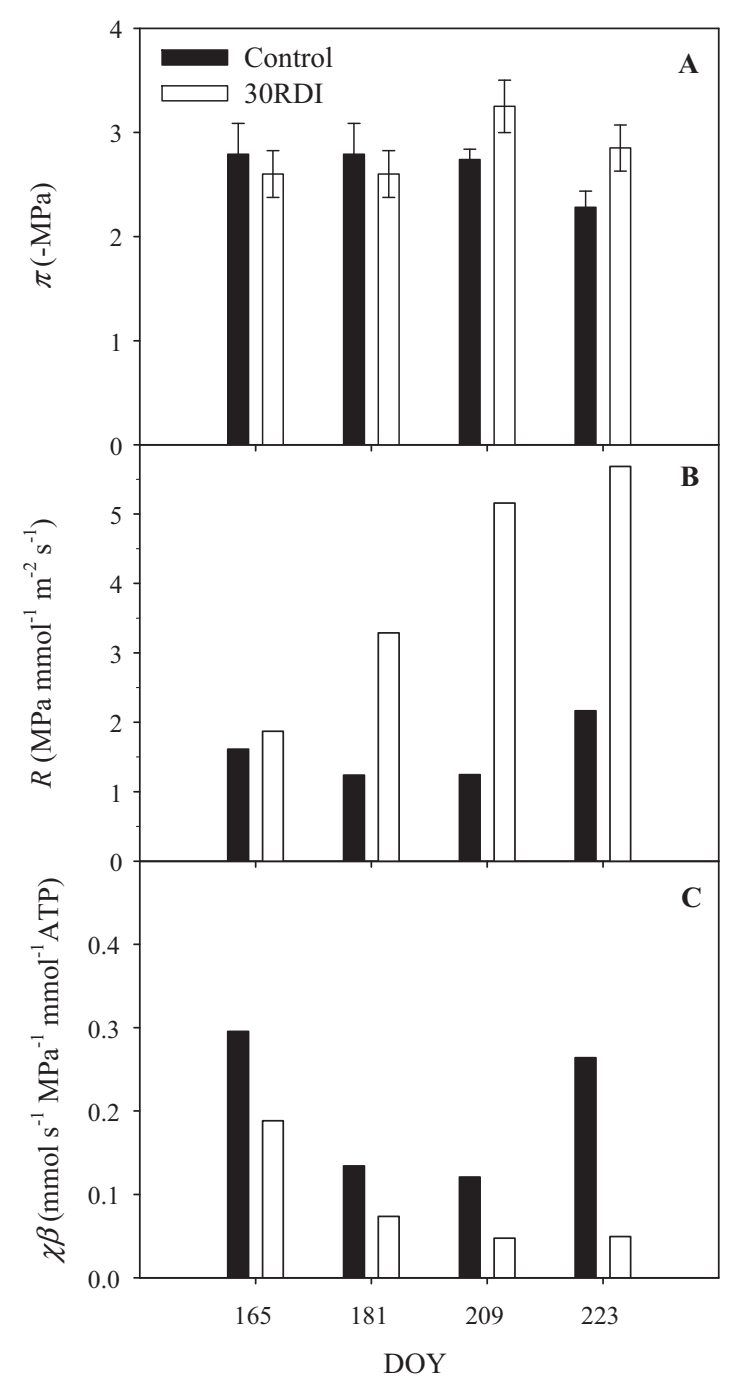

Fig. 10. Values of the BMF parameters for the four days in which we measured leaf gas exchange and leaf water potential (see Table 2). (A) Measured osmotic pressure of leaves $(\pi, n=8)$. (B) Soil-to-leaf hydraulic conductance $(R)$. (C) Sensitivity of the hydroactive mechanism of response of guard cells to turgor pressure $(\chi \beta)$. This parameter is potentially related to ABA. Both $R$ and $\chi \beta$ were modeled parameters.

(2) What is limiting $E_{\mathrm{p}}$ in Control trees during early summer in comparison to late summer?

Our recent research in a nearby olive orchard may help to answer the first question. Fernández et al. (2003) and Palomo et al. (2002) worked with 'Manzanilla' olive trees at La Hampa orchard, at $15 \mathrm{~km}$ southwest of Seville, and found a slower reduction in $E_{\mathrm{p}}$, in trees under DI and dry-farming conditions, than the measured in this study (Sanabria orchard). The simplest explanation is that water depletion from soil was slower and the access to soil water was larger in the La Hampa study than in the present (Sanabria) study. This is supported by the high $\Psi_{\text {pd }}$ values measured in summer in non-irrigated trees at La Hampa, and by the slow decrease of $E_{\mathrm{p}}$ even in periods of several weeks without any water supply (Fernández et al., 2008b). Trees at La Hampa are older than at Sanabria (45- vs 5-years old) and of bigger size $\left(50 \mathrm{~m}^{2} \mathrm{vs}\right.$ $\left.12 \mathrm{~m}^{2} A_{\mathrm{L}}\right)$, but lower LAI $\left(1 \mathrm{~m}^{2} \mathrm{~m}^{-2}\right.$ vs $\left.1.43 \mathrm{~m}^{2} \mathrm{~m}^{-2}\right)$. However, the main difference between these orchards involves the soil and rhizosphere. The soil at La Hampa is deeper (up to $2 \mathrm{~m}$ deep) and roots of non-irrigated trees explore a greater volume of soil, ca. $32 \mathrm{~m}^{3}$ (Fernández et al., 1991, 2008c) than in Sanabria. The average RLD is about $0.2 \mathrm{~cm} \mathrm{~cm}^{-3}$ (Fernández et al., 1991). This suggests $A_{\mathrm{R}}=100 \mathrm{~m}^{2}$, and therefore an $A_{\mathrm{R}}: A_{\mathrm{L}}=3.34$ vastly greater than the
$A_{\mathrm{R}}: A_{\mathrm{L}}=0.38$ estimated for Sanabria and than the value of 1.0 used for the simulation in Fig. 7. The low $A_{R}: A_{L}$ value for Sanabria is due to the shallow establishment of the rhizosphere in the soil profile. Roots were not found below $0.45 \mathrm{~m}$, and most of them were enclosed in the wet bulbs (Fig. 3). When dry, the deeper layer of soil, richer in clay, shows a high resistance to penetration. When wet, the low hydraulic conductivity favored hypoxia conditions, which it is known to restrict olive root growth (Fernández and Moreno, 1999). 'The $\theta$ values that were almost continuously near saturation in this layer were probably not amenable to root growth. The slope of the relationship between RLD and intersection point density in the trench wall, close to 2 (Fig. 2), suggests an isotropic root growth, i.e., roots grew in all directions of space (Lopez-Zamora et al., 2002). This is what it can be expected from a localized irrigation system where most of the roots are concentrated in the wet bulbs and nearby regions (Pires et al., 2011). In addition to this, olive trees at Sanabria are relatively young and have been growing under drip irrigation conditions since planting. Therefore, they have acclimated their root development to this spatial availability of water. Moreover, the soil's high sand content makes $K_{\mathrm{s}}$ very sensitive to changes in the soil moisture (Fig. 6), i.e., small chamges in $\theta$ produces large changes in $K_{\mathrm{s}}$. These two circumstances - a reduced rhizosphere and very coarse soil - make transpiration very dependent on the frequency and amount of irrigation events, due to the low buffer capacity of the soil.

The answer to the second question, what limits $E_{\mathrm{p}}$ in Control trees in early summer, is partly implicit in the preceding discussion. Although $E_{\mathrm{p}}$ was higher in Control trees on DOY 208 than on DOY $167, g_{c}$ reached a higher peak value early in the morning on DOY 167 than on DOY 208 (data not shown). Differences in VPD values were not significant, but their diurnal shape was; the difference arose from greater $g_{c}$ at mid-day on DOY 208 when VPD was maximum. This was probably due to the greater irrigation applied on DOY 208 (28 L tree $^{-1}$ ) vs on DOY $167\left(18 \mathrm{Ltree}^{-1}\right)$, which could have led to large differences, both in $\Psi_{\mathrm{s}}$ and $K_{\mathrm{s}}$, in this sensitive soil. The agronomical implications for this observation might be negligible, but the analysis of this observation will help us to explore the sensitivity of the BMF model later on.

The seasonal evolution of $g_{s}$ measured in sunlit leaves (Table 2) shows that while the stomata of the Control trees remained fully open, that of the 30RDI trees was reduced by half soon after the frequency of irrigation decreased to once per week. By the end of the summer $g_{s}$ was reduced more than 3 -fold. $g_{s}$ was strongly correlated with $\Psi_{1}$ down to $0.1 \mathrm{~mol} \mathrm{~m}^{-2} \mathrm{~s}^{-1}$, but below this point the response became less steep. Olive has been reported as a nearisohydric species (Cuevas et al., 2010), able to maintain nearly constant $\Psi_{1}$ under varying evaporative demand, whereas our data indicate substantial changes in $\Psi_{1}$ under varying $\Psi_{\mathrm{s}}$. Our results, then, are more in agreement with those of Tognetti et al. (2009), who concluded that olive had an anisohydric behavior under the conditions of their study. Our findings, however, are not contradictory with those of Cuevas et al. (2010). Hacke et al. (2000) demonstrated that the isohydric and anisohydric behaviors depend on the type of soil where the plant grows. Loamy soils favor isohydric behavior meanwhile sandy soils do anisohydric. This is related to the hydraulic limits imposed by soil and plant, which will be seen in detail in the next section.

\subsection{Results from a hydraulic model}

Are there hydraulic constraints for transpiration in our olive orchard, and if so, are they due to soil or plant? The SACC model (Sperry et al., 1998) is uniquely suited to answer this question. Some species can maintain transpiration and survive at very low $\Psi_{\text {s }}$, like Artemisia tridentata (Kolb and Sperry, 1999), while others, like Betula occidentalis, cannot (Sperry et al., 2002). Similarly, 
plants growing on nearby soils of different characteristics, like the case of a Pinus taeda stand planted on a patchy soil (Hacke et al., 2000), showed very different canopies and patterns in water use. The model predicts a water use envelope that sets the limit for transpiration as a function of $\Psi_{s}$; beyond this limit, the plant would suffer catastrophic failure of its hydraulic system. As far as we know, this model has not yet been applied to woody fruit trees or to the management of irrigation. The discussion above highlights the role of our orchard's soils in setting hydraulic limits on water use. Fig. 7 shows the water use envelope for trees with a root to leaf area ratio $\left(A_{\mathrm{R}}: A_{\mathrm{L}}\right)$ of 0.38 (our trees at Sanabria), in comparison to actual data. The measured $E_{\mathrm{p}}$ was below the boundary line over the entire range of $\Psi_{\mathrm{s}}$ measured. Exceptionally, some points at low $\Psi_{\mathrm{s}}$ are above the line; however, this can be explained by the inaccuracy in the estimation of a single bulk value of $\Psi_{\mathrm{s}}$ while attempting to represent the whole soil profile. This is especially true in soils that have very heterogeneous $\theta$ distribution due to drip irrigation, like the one at Sanabria. Despite this, the performance of the model is good, and explains our data satisfactorily. The difference between the model and the actual transpiration is wider at high $\Psi_{\mathrm{s}}$ than at lower ones. In other words, there is a larger safety margin at high $\Psi_{\mathrm{s}}$ than at low ones, where actual values of $E_{\mathrm{p}}$ get closer to the envelope. This was already observed by Sperry et al. $(1998,2002)$ in other species. In general, our conditions of sandy soil with a shallow root system favor the existence of a low $A_{R}: A_{L}$, which "pushes" the envelope to actual values of $E_{\mathrm{p}}$ at relatively high $\Psi_{\mathrm{s}}$.

Most plants usually do not modify the vulnerability of their hydraulic system in response to drought (Cornwell et al., 2007; Maherali and DeLucia, 2000; Fichot et al., 2010), although some species have been reported to do so (Beikircher and Mayr, 2009; Fichot et al., 2010; Kolb and Sperry, 1999). Of course, they cannot modify the soil texture either. The main variable that plants regulate to influence the shape of the water use envelope is the $A_{\mathrm{R}}: A_{\mathrm{L}}$. Fig. 7 shows how an increase from $A_{\mathrm{R}}: A_{\mathrm{L}}=0.38$ to 1 makes transpiration approach the critical $E_{\mathrm{p}}$ at $\Psi_{\mathrm{s}}$ much lower than $-3 \mathrm{MPa}$. For a species like olive with a high resistance to xylem cavitation, an increase in $A_{\mathrm{R}}: A_{\mathrm{L}}$ allows the plant to function at extremely low $\Psi_{\mathrm{s}}$ without reaching the permanent wilting point. A value of $A_{\mathrm{R}}: A_{\mathrm{L}}=3.34$ was calculated at La Hampa orchard, indicating no limitation by the rhizosphere in that location. The stomatal control of actual $E_{\mathrm{p}}$ shown in Fig. 7 agrees with measurements of $g_{\mathrm{s}}$ at the leaf level. At $\Psi_{\mathrm{s}}=-1.5 \mathrm{MPa}_{\mathrm{s}}$ was $0.69 \mathrm{~mol} \mathrm{~m}^{-2} \mathrm{~s}^{-1}$. And in the previous year, 2010, $\Psi_{\mathrm{s}}$ dropped to $-3 \mathrm{MPa}$ for a $g_{\mathrm{s}}$ of $0.048 \mathrm{~mol} \mathrm{~m}^{-2} \mathrm{~s}^{-1}$ (data not published), which indicates a nearly total stomata closure. We must be aware of the lack of information about $A_{R}$ evolution, in contrast to the well described evolution of $A_{\mathrm{L}}$. This could modify slightly the value of 0.38 estimated. We think, however, that the bias is not important since the volume of soil for active growing is limited to wet bulbs, where we have measured RLD values close to the maximum values reported by olive orchards under drip irrigation (Fernández et al., 1991).

The effect of greater xylem vulnerability can be evaluated with grapevine simulations (Figs. 6 and 7). Grapevines planted at Sanabria and with an $A_{R}: A_{L}=0.38$ would not be able to maintain the same $E_{\mathrm{p}}$ as olive. Assuming a potential $E_{\mathrm{p}}$ of $1.3 \mathrm{mmol} \mathrm{m}^{-2} \mathrm{~s}^{-1}$, similar to that for olive in this study, and considering that the safety margin is maintained at high $\Psi_{\mathrm{s}}$ despite the decreasing water use envelope (Sperry et al., 2002, Fig. 3), maximum $E_{\mathrm{p}}$ would be reduced by half. Increasing $A_{R}: A_{L}$ to 1.0 eliminates this limitation at high $\Psi_{\mathrm{S}}$, and allows grapevine to approach the extraction limit of around $-5 \mathrm{MPa}$ imposed by the xylem. Changes in $A_{\mathrm{R}}: A_{\mathrm{L}}$ could be achieved not only by increasing $A_{\mathrm{R}}$ but also by decreasing $A_{\mathrm{L}}$. Some species like Quercus canariensis and $Q$. faginea, typical of our latitudes, are semi-deciduous, i.e., their leaves drop in summer, which reduces $A_{\mathrm{L}}$. In some species adapted to arid environments the reduction of
$A_{\mathrm{L}}$ in summer can be extremely severe, provoking leafless branches (Miranda et al., 2010).

Contrary to what happens in plants under natural conditions, farmers can modify the $A_{\mathrm{R}}: A_{\mathrm{L}}$ ratio by changing both $A_{\mathrm{R}}$ and $A_{\mathrm{L}}$. Fig. 8 shows a simulation of the impact of a changing LAI on $E_{\mathrm{p}}$ if $A_{\mathrm{R}}$ is kept constant. $E_{\mathrm{p}}$ is decreased by $50 \%$. In olive, as in most crops, yield is directly related to water transpired by the plant (Moriana et al., 2003; Fereres and Soriano, 2007). The simulation rests on two assumptions. One is that $A_{\mathrm{R}}$ is maintained, which is likely due to the limitation of volume of wet soil imposed by localized irrigation and the high RLD already found. The second assumption is that the increment in $E_{\mathrm{p}}$ with increasing LAI is not dependent on a different percentage of sunny and shaded leaves. We did not consider, in the simulation, that increasing LAI enhances the number of shaded leaves vs sunny leaves. But if that effect is taken into account, the assumption also holds, as Fernández et al. (2008c) demonstrated using a multilayer radiation interception model. The simulation in Fig. 8 shows an important impact of the pruning management in the orchard, and sets an optimal LAI value for an irrigation system with three drippers per tree. However, larger yield will be obtained from larger LAI, since more shoots are able to carry fruits. On the other side, the reduction in $E_{\mathrm{p}}$ due to the increasing LAI could have a negative impact on yield. Currently, we have no answer to this trade-off. However, farmers can influence $A_{\mathrm{R}}$ to compensate for increasing values of $A_{\mathrm{L}}$. The question is: how many drippers do we need to install per tree to recover $E_{\mathrm{p}}$ (to that at previous values of LAI) if we double LAI? The answer can be assessed by the model changing the volume of soil wetted by a dripper and considering steady RLD. The double LAI is nearly compensated by increasing the number of drippers from three to five.

\subsection{A model for the actual transpiration}

We have seen how the SACC model can predict hydraulic limits based on plant and soil characteristics, and how it can be applied to orchard management. However, this model was not designed to predict diurnal courses of actual transpiration, unless the diurnal course of $\Psi_{1}$ is input as well. Additional insights can be gained by simulating stomatal responses to atmospheric demand and soil water deficit. In canopies well coupled to the atmosphere most of the transpiration is driven by VPD (Jarvis and McNaughton, 1986). This is the case of olive tree orchards (Moreno et al., 1996; Tognetti et al., 2009). An important characteristic of well coupled canopies is that $g_{s}$ exerts a strong control of transpiration. This means that if we can model $g_{s}$ satisfactorily, we can predict $E_{\mathrm{p}}$. Traditionally, the most widely used $g_{s}$ models have been those of Jarvis (1976) and Leuning (1995). However, these models, although able to mimic the stomatal response in most simulations, have difficulty simulating the effect of water stress (Vico and Porporato, 2008; Egea et al., 2011). Several attempts have been made to consider the response of stomata to a drying soil, for instance by including the effect of ABA (Gutschick and Simonneau, 2002), which has been reported to act as a chemical signal from roots to leaves. Egea et al.(2011) found a suitable solution by including a soil moisture dependent function to account for the effects of water stress on $g_{s}$. The hydromechanical model proposed by Buckley et al. (2003) (BMF) has not been widely applied yet and it has an advantage over most others in that its parameters have explicit physiological meaning. Recent reviews on this topic (Damour et al., 2010; Egea et al., 2011) recognized the potential of this model, but noted the difficulty in applying it, due to its high number of parameters. Our results show we were able to apply and validate a slightly simplified form of this model.

We estimated canopy conductance $\left(g_{c}\right)$ from sap flow data as a surrogate of $g_{s}$ (Fig. 9) in order to obtain long time series of this variable. Values of $g_{c}$ compared well with $g_{s}$ measurements made at the leaf level. In these same trees, $g_{s}$ measured in sunny and shaded 
leaves were on average $0.23 \mathrm{~mol} \mathrm{~m}^{-2} \mathrm{~s}^{-1}$ and $0.07 \mathrm{~mol} \mathrm{~m}^{-2} \mathrm{~s}^{-1}$, respectively. Assuming a fraction of sunny leaf area between 0.2 and 0.3 (based on measurements by Moreno et al., 1996, lowered from their value of 0.3 to account for mutual shading in hedgerows), the $g_{c}$ value obtained is very similar to the value estimated from leaf gas exchange. The BMF model fitted our data quite well in both treatments as soil dried out (Fig. 9). The model's real strength, however, is that it allowed us to analyze the physiological parameters obtained (Fig. 10). In our case, only two parameters of three were fitted. The seasonal evolution of $\pi$ shows that similar osmotic adjustment occurred in both treatments. This was especially strong in Control on DOY 209 since $\Psi_{1}$ was only $-1.37 \mathrm{MPa}$. Osmotic adjustment has been interpreted as a mechanism for maintaining leaf turgor pressure when $\Psi_{1}$ is reduced to withdraw water from drying soils (Dichio et al., 2005). In the case of 30RDI this explanation fits perfectly. $\Psi_{1}$ on DOY 209 was as low as $-2.96 \mathrm{MPa}$ and $\pi=-3.03 \mathrm{MPa}$. Therefore, another explanation is required for the osmotic accumulation observed in the Control treatment. One possibility is accumulation of photosynthates, which would build up a high $\pi$ to facilitate the transport of assimilates to phloem. The theory of passive loading to phloem for the primary photoassimilates, sucrose and sugar alcohols, could explain this increase in $\pi$ independently of a response to water stress (Rennie and Turgeon, 2009). Species accumulating mannitol, like olive (Flora and Madore, 1993), use this strategy preferentially, probably because it requires no energy (Reidel et al., 2009). This explanation agrees well with the activation of growing in Control trees from DOY 190 (Fig. 4). Although this hypothesis deserves further experimental study, it might have important implications in the identification of the growth inhibition threshold for olive, and the determination of optimal water potentials for managing irrigation.

One parameter fitted by the model is plant hydraulic resistance, $R$ (Fig. 10B). The small increase in $R$ observed in Control trees was expected, since $\Psi_{\mathrm{s}}$ did not exceed $-0.4 \mathrm{MPa}$ in the whole period, and $\Psi_{1}$ was never lower than $-1.4 \mathrm{MPa}$. On the contrary, 30RDI experienced a progressive increase in $R$, in agreement with the decrease in $\Psi_{\mathrm{s}}$. The seasonal pattern of both treatments fits well to data of $R_{\mathrm{p}}$ shown in Table 2. Differences in absolute values of both variables also highlight the importance of the soil component included in $R$ : these differences increased as soil dried out, as suggested by Sperry (2000). Similar values of $R_{\mathrm{p}}$ and its seasonal evolution have been reported previously for olive (Tognetti et al., 2009), as well as for other Mediterranean tree species like Quercus rotundifolia (David et al., 2004), but we have not found in the literature such a marked difference between controls and stressed plants under field conditions as in this study. The likely explanation for this behavior is the small $A_{\mathrm{R}}: A_{\mathrm{L}}$ in our olive trees. The reduced IAs and low irrigation frequency in 30RDI affected the hydraulic capacity of the plant. Despite this constraint in $A_{\mathrm{R}}$, Control plants did not experience important changes in their $R$. The daily irrigation with sufficient IAs was enough to maintain a nearly steady maximum $E_{\mathrm{p}}$. However, it is important to note that the increase in $R$ in 30RDI looks disproportionate to the PLC predicted by the vulnerability curve on Fig. 6. PLC on this figure refers only to shoot xylem vulnerability to cavitation, while $R$ comprises the soil-to-leaf continuum. This means that the increase in $R$ arose elsewhere in the plant, likely roots or leaves. Indeed, the vulnerability to cavitation has been reported to be higher in both roots (Alder et al., 1996; Kolb and Sperry, 1999) and leaves (Brodribb and Holbrook, 2003; Zufferey et al., 2011), than in the xylem. Vulnerability to cavitation in petiole and leaf lamina have been recognized in recent years to play an important role in stomatal regulation (e.g., Guyot et al., 2011).

The other fitted parameter, $\chi \beta$, represents the sensitivity of guard cells to changes in turgor pressure. Unlike $R, \chi \beta$ showed clear seasonal dynamics in both treatments (Fig. 10C). $\chi \beta$ includes the effect of guard cell solute efflux, so it should decline in response to hormonal signals from drying roots, like ABA (Buckley, 2005). This is consistent with the inferred seasonal patterns. $\chi \beta$ also includes the effect of stomatal size and density, which were similar between treatments in this study (data not shown). Our data suggest that the putative drought signal was stronger in 30RDI for most dates. On DOY $165 \chi \beta$ was one-third as high in Control than in 30RDI, before declining to a minimum in both treatments on DOY 209 and then recovering on DOY 223. The main conclusion is that the stomatal sensitivity to leaf water status was regulated seasonally not only in 30RDI, but also in well-irrigated Control trees - suggesting that $\chi \beta$ is not primarily regulated by soil moisture (nor, by inference, by ABA signals from droughted roots) in this species. This is consistent with some research suggesting that $A B A$ is synthesized primarily in leaves, rather than in roots (Holbrook et al., 2002; Christmann et al., 2005), and that the travel time of ABA in woody species may be too great for it to serve as a rapid long distance signal (Perks et al., 2002).

To sum up this section, application of the BMF model to our data suggests that stomata in olive are regulated seasonally by something other than purely hydraulic signals, and that this occurs not only in droughted but also in well-watered trees. These signals might be chemical (for example ABA, nitric oxide, reactive oxygen species, etc.; Jiang and Zhang, 2001; Neill, 2007), or physical (for example electric signals, Stahlberg et al., 2001; Oyarce and Gurovich, 2011). Additionally, hydraulic capacity of plants receiving only $30 \%$ of water supplied to Control is severely affected under our conditions of climate, soil and irrigation strategy. In any case, the BMF model can serve as a useful research tool to understand the mechanisms behind observations, and as a platform to accommodate experimental knowledge from the literature.

\section{Conclusions}

The use of two process-based models helped us to advance understanding of water use by an olive orchard planted in hedgerow. The SACC model confirmed that the main limitation in the water use by olive trees in this orchard was in their rhizosphere. The limited volume of wet soil, determined by the number of drippers, reduced the ratio of root to leaf area. This reduction imposed a large hydraulic limitation to transpiration as bulk soil water potential decreased. The model was able to predict the impact of soil type, ratio of root and leaf areas on the limit of extraction of water by the plant. This has important practical implications for pruning and irrigation management, as the model can be used to assess the impact of changes in leaf area and number of drippers. Increasing the number of drippers from the actual three to five would be necessary to compensate for two-fold increment in leaf area if the goal were to keep maximum transpiration values. The BMF model simulated satisfactorily the actual canopy conductance on several dates through the summer, both in well-watered and water stressed plants. Plants of both water treatments made similar osmotic adjustment. However, soil-to-leaf hydraulic resistance in stressed plants increased more than 4-fold during the summer. A potential involvement of regulating signals, other than purely hydraulics, was evident in both treatments, although our data suggests that these signals were themselves regulated by something other than soil water status.

\section{Acknowledgments}

This experiment was funded by the Spanish Ministry of Science and Innovation, research project AGL2009-11310/AGR, Junta de Andalucía, AGR-6456-2010 and co-funded by FEDER programme. C.M. R-D, J.M. T-R and S. E-F benefited from a FPDI research fellowship from the Junta de Andalucía, a FPI grant from the Spanish 
Ministry of Science and Innovation, and a JAE-predoc fellowship of CSIC, respectively. Antonio Montero helped us with the field measurements. Thanks are due to the owners of Internacional Olivarera, S.A.U. (Interoliva), for allowing us to make the experiments in the Sanabria orchard. Thanks to Dr. F. Villalobos for his advice on with the use of the LAI-2200 in our orchard. We also thank Silvia Seller, agronomist, and Juan Francisco Bernabé, foreman, for their technical assistance.

\section{References}

Alder, N.N., Sperry, J.S., Pockman, W.T., 1996. Root and stem xylem embolism stomatal conductance, and leaf turgor in Acer grandidentatum populations along a soil moisture gradient. Oecologia 105, 293-301.

Allen, R., Pereira, L.S., Raes, D., Smith, M., 1998. Crop evapotranspiration - Guidelines for computing crop water requirements. FAO Irrigation and Drainage Paper No. 56, Rome, Italy. http://www.fao.org/docrep/X0490E/X0490E00.htm.

Ball, J.T., Woodrow, I.E., Berry, J.A., 1987. A model predicting stomatal conductance and its contribution to the control of photosynthesis under different environmental conditions. In: Biggens, J. (Ed.), Progress in Photosynthesis Research. Martinus Nijhoff Publishers, the Netherlands, pp. 221-224.

Beikircher, B., Mayr, S., 2009. Intraspecific differences in drought tolerance and acclimation in hydraulics of Ligustrum vulgare and Viburnum lantana. Tree Physiology 29, 765-775.

Brodribb, T.J., Holbrook, N.M., 2003. Stomatal closure during leaf dehydration correlation with other leaf physiological traits. Plant Physiology 132, 2166-2173.

Buckley, T.N., 2005. The control of stomata by water balance. New Phytologist 168, 275-291.

Buckley, T.N., Mott, K.A., Farquhar, G.D., 2003. A hydromechanical and biochemical model of stomatal conductance. Plant, Cell \& Environment 26, 1767-1785.

Callister, A.N., Arndt, S.K., Adams, M.A., 2006. Comparison of four methods for measuring osmotic potential of tree leaves. Physiologia Plantarum 127, 383-392.

Campbell, G.S., 1985. Soil physics with BASIC - Transport models for soil-plant systems. In: Developments in Soil Science 14. Elsevier, New York.

Chaves, M.M., Pereira, J.S., Maroco, J., Rodrigues, M.L., Ricardo, C.P.P., Osorio, M.L., Carvalho, I., Faria, T., Pinheiro, C., 2002. How plants cope with water stress in the field. Photosynthesis and growth. Annals of Botany 89, 907-916.

Choat, B., Drayton, W.M., Brodersen, C.R., Matthews, M.A., Shackel, K.A., Wada, H., McElrone, A.J., 2010. Measurement of vulnerability to water stress-induced cavitation in grapevine: a comparison of four techniques applied to long-vesseled species. Plant, Cell and Environment 33, 1502-1512.

Christmann, A., Hoffmann, T., Teplova, I., Grill, E., Muller, A., 2005. Generation of active pools of abscisic acid revealed by in vivo imaging of water-stressed Arabidopsis. Plant Physiology 137, 209-219.

Cornwell, W.K., Bhaskar, R., Sack, L., Cordell, S., Lunch, C.K., 2007. Adjustment of structure and function of Hawaiian Metrosideros polymorpha at high vs low precipitation. Functional Ecology 21, 1063-1071.

Cuevas, M.V., Torres-Ruiz, J.M., Álvarez, R., Jiménez, M.D., Cuerva, J., Fernández, J.E., 2010. Usefulness of trunk diameter variations for irrigation scheduling in a mature olive tree orchard. Agricultural Water Management 97, 1293-1302.

Damour, G., Simonneau, T., Cochard, H., Urban, L., 2010. An overview of models of stomatal conductance at the leaf level. Plant, Cell \& Environment 33,1419-1438.

David, T.S., Ferreira, M.I., Cohen, S., Pereira, J.S., David, J.S., 2004. Constraints on transpiration from an evergreen oak tree in southern Portugal. Agricultural and Forest Meteorology 122, 193-205.

Dewar, R.C., 2002. The Ball-Berry-Leuning and Tardieu-Davies stomatal models: synthesis and extension within a spatially aggregated picture of guard cell function. Plant, Cell \& Environment 25, 1383-1398.

Diaz-Espejo, A., Walcroft, A.S., Fernández, J.E., Hafidi, B., Palomo, M.J., Girón, I.F., 2006. Modeling photosynthesis in olive leaves under drought conditions. Tree Physiology 26, 1445-1456.

Dichio, B., Xiloyannis, C., Sofo, A., 2005. Osmotic regulation in leaves and roots of olive trees during a water deficit and rewatering. Tree Physiology 26, 179-185.

Egea, G., Verhoef, A., Vidale, P.L., 2011. Towards an improved and more flexible representation of water stress in coupled photosynthesis - stomatal conductance models. Agricultural and Forest Meteorology 151, 1370-1384.

Farquhar, G.D., von Caemmerer, S., Berry, J.A., 1980. A biochemical model of photosynthetic CO2 assimilation in leaves of $C_{3}$ species. Planta 149, 78-90.

Farquhar, G.D., Wong, S.C., 1984. An empirical model of stomatal conductance. Australian Journal of Plant Physiology 11, 191-210.

Fereres, E., Castel, J.R., 1981. Drip Irrigation Management. Division of Agricultural Sciences, University of California (Leaflet 21259).

Fereres, E., Soriano, M.A., 2007. Deficit irrigation for reducing agricultural water use. Journal of Experimental Botany 58, 147-159.

Fernández, J.E., Cuevas, M.V., 2010. Irrigation scheduling from stem diameter variations: a review. Agricultural and Forest Meteorology 150, 135-151.

Fernández, J.E., Diaz-Espejo, A., Infante, J.M., Durán, P., Palomo, M.J., Chamorro, V., Girón, I.F., Villagarcía, L., 2006a. Water relations and gas exchange in olive trees under regulated deficit irrigation and partial rootzone drying. Plant and Soil 284, 271-287.

Fernández, J.E., Durán, P.J., Palomo, M.J., Diaz-Espejo, A., Chamorro, V., Girón, I.F., 2006b. Calibration of sap flow measurements by the compensation heat-pulse method in olive, plum and orange trees: relations with xylem anatomy. Tree Physiology 26, 719-728.

Fernández, J.E., Green, S.R., Caspari, H.W., Diaz-Espejo, A., Cuevas, M.V., 2008a. The use of sap flow measurements for scheduling irrigation in olive apple and Asian pear trees and in grapevines. Plant and Soil 305, 91-104.

Fernández, J.E., Romero, R., Montaño, J.C., Diaz-Espejo, A., Muriel, J.L., Cuevas, M.V., Moreno, F., Girón, I.F., Palomo, M.J., 2008b. Design and testing of an automatic irrigation controller for fruit tree orchards based on sap flow measurements. Australian Journal of Agricultural Research 59, 589-598.

Fernández, J.E., Diaz-Espejo, A., d'Andria, R., Sebastiani, L., Tognetti, R., 2008c. Potential and limitations of improving olive orchard design and management through modelling. Plant Biosystems 142 (1), 130-137.

Fernández, J.E., Moreno, F., 1999. Water use by the olive tree. Journal of Crop Products $2,101-162$

Fernández, J.E., Moreno, F., Cabrera, F., Arrue, J.L., Martín-Aranda, J., 1991. Drip irrigation, soil characteristics and the root distribution and root activity of olive trees. Plant and Soil 133, 239-251.

Fernández, J.E., Palomo, M.J., Diaz-Espejo, A., Giron, I.F., 2003. Influence of partial soil wetting on water relation parameters of the olive tree. Agronomie 23 545-552.

Fernández, J.E., Rodriguez-Dominguez, C.M., Perez-Martin, A., Zimmermann, U. Rüger, S., Martín-Palomo, M.J., Torres-Ruiz, J.M., Cuevas, M.V., Sann, C., Ehrenberger, W., 2011. Online-monitoring of tree water stress in a hedgerow olive orchard using the leaf patch clamp pressure probe. Agricultural Water Management 100, 25-35.

Fichot, R., Barigah, T.S., Chamaillard, S., Le Thiec, D., Laurans, F., Cochard, H., Brignolas F., 2010. Common trade-offs between xylem resistance to cavitation and other physiological traits do not hold among unrelated Populus deltoids $\times$ Populus nigra hybrids. Plant, Cell \& Environment 33, 1553-1568.

Flora, L., Madore, M.A., 1993. Stachyose and mannitol transport in olive (Olea europaea L.). Planta 189, 484-490.

Gao, Q., Zhao, P., Zeng, X., Cai, X., Shen, W., 2002. A model of stomatal conductance to quantify the relationship between leaf transpiration, microclimate and soil water stress. Plant, Cell \& Environment 25, 1373-1381.

Green, S.R., Clothier, B.E., Jardine, B., 2003. Theory and practical application of heatpulse to measure sap flow. Agronomy Journal 95, 1371-1379.

Gutschick, V.P., Simonneau, T., 2002. Modelling stomatal conductance of field-grown sunflower under varying soil water content and leaf environment: comparison of three models of stomatal response to leaf environment and coupling with an abscisic acid based model of stomatal response to soil drying. Plant, Cell \& Environment 25, 1423-1434.

Guyot, G., Scoffoni, C., Sack, L., 2011. Combined impacts of irradiance and dehydration on leaf hydraulic conductance: insights into vulnerability and stomatal control. Plant, Cell \& Environment, http://dx.doi.org/10.1111/j. 13653040.2011.02458.x

Hacke, U.G., Sperry, J.S., Ewers, B.E., Ellsworth, D.S., Schafer, K.V.R., Oren, R. 2000. Influence of soil porosity on water use in Pinus taeda. Oecologia 124 495-505.

Holbrook, N.M., Shashidhar, V.R., James, R.A., Munns, R., 2002. Stomatal contro in tomato with ABA-deficient roots: response of grafted plants to soil drying. Journal of Experimental Botany 53, 1503-1514.

Jarvis, A.J., Davies, W.J., 1998. The coupled response of stomatal conductance to photosynthesis and transpiration. Journal of Experimental Botany 49, 399-406.

Jarvis, P.G., 1976. Interpretation of variations in leaf water potential and stomata conductance found in canopies in field. Philosophical Transactions of the Roya Society of London. Series B, Biological Sciences 273, 593-610.

Jarvis, P.G., McNaughton, K.G., 1986. Stomatal control of transpiration: scaling up from leaf to region. Advances in Ecological Research 15, 1-49.

Jiang, M., Zhang, J., 2001. Effect of abscisic acid on active oxygen species, antioxidative defense system and oxidative damage in leaves of maize seedlings. Plant and Cell Physiology 42, 1265-1273.

Jones, H.G., 1999. Use of infrared thermometry for estimation of stomatal conductance as a possible aid to irrigation scheduling. Agricultural and Forest Meteorology 95, 139-149.

Kolb, K.J., Sperry, J.S., 1999. Transport constraints on water use by the Great Basin shrub, Artemisia tridentata. Plant, Cell \& Environment 22, 925-935.

Leuning, R., 1995. A critical-appraisal of a combined stomatal - photosynthesis model for C-3 plants. Plant, Cell \& Environment 18, 339-355.

Lopez-Zamora, I., Falcao, N., Comerford, N.B., Barros, N.F., 2002. Root isotropy and an evaluation of a method for measuring root distribution in soil trenches. Forest Ecology and Management 166, 303-310.

Maherali, H., DeLucia, E.H., 2000. Xylem conductivity and vulnerability to cavitation of ponderosa pine growing in contrasting climates. Tree Physiology 20, 859-867.

McDowell, N., Pockman, W.T., Allen, C.D., Breshears, D.D., Cobb, N., et al., 2008 Tansley review. New Phytologist 178, 719-739.

Messinger, S.M., Buckley, T.N., Mott, K.A., 2006. Evidence for involvement of photosynthetic processes in the stomatal response to $\mathrm{CO}_{2}$. Plant Physiology 140 , 771-778.

Miranda, J.D., Padilla, F.M., Martínez-Vilalta, J., Pugnaire, F.I., 2010. Woody species of a semi-arid community are only moderately resistant to cavitation. Functional Plant Biology 37, 828-839.

Moreno, F., Fernandez, J.E., Clothier, B.E., Green, S.R., 1996. Transpiration and roo water uptake by olive trees. Plant and Soil 184, 85-96.

Moriana, A., Orgaz, F., Pastor, M., Fereres, E., 2003. Yield responses of a mature olive orchard to water deficits. Journal of the American Society for Horticultura Science 128 (3), 425-431. 
Nadler, A., Tyree, M.T., 2008. Substituting stem's water content by electrical conductivity for monitoring water status changes. Soil Science Society of America Journal 72, 1006-1013.

Neill, S., 2007. Interactions between abscisic acid, hydrogen peroxide and nitric oxide mediate survival responses during water stress. New Phytologist 175, 4-6.

Neumann, P., 2008. Coping mechanisms for crop plants in drought-prone environments. Annals of Botany 101, 901-907.

Ortuño, M.F., Conejero, W., Moreno, F., Moriana, A., Intrigliolo, D.S., Biel, C.A., Mellisho, C.A.D., Pérez-Pastor, A., Domingo, R., Ruiz-Sánchez, M.C.A., Casadesus, J., Bonany, J., Torrecillas, A., 2010. Could trunk diameter sensors be used in woody crops for irrigation scheduling? A review of current knowledge and future perspectives. Agricultural Water Management 97, 1-11.

Oyarce, P., Gurovich, L., 2011. Evidence for the transmission of information through electric potentials in injured avocado trees. Journal of Plant Physiology 168, 103-108.

Palomo, M.J., Moreno, F., Fernandez, J.E., Diaz-Espejo, A., Giron, I.F., 2002. Determining water consumption in olive orchards using the water balance approach. Agricultural Water Management 55, 15-35.

Pardossi, A., Incrocci, L., 2011. Traditional and new approaches to irrigation scheduling in vegetable crops. HortTechnology 21 (3), 309-313.

Peak, D., Mott, K.A., 2011. A new, vapour-phase mechanism for stomatal responses to humidity and temperature. Plant, Cell \& Environment 34, 162-178.

Perks, M.P., Irvine, J., Grace, J., 2002. Canopy stomatal conductance and xylem sap abscisic acid (ABA) in mature Scots pine during a gradually imposed drought. Tree Physiology 22, 877-883.

Pires, R.C.M., Bodine, J.D., Sakai, E., Villa, H.L., da Silva, T.J.A., Arruda, F.B., 2011. Effect of trickle irrigation on root development of the wet bulb and 'Pera' orange tree yield in the state of Sao Paulo, Brazil. Engenharia Agricola 31, 1096-1103.

Reidel, E.J., Rennie, E.A., Amiard, V., Cheng, L., Turgeon, R., 2009. Phloem loading strategies in three plant species that transport sugar alcohols. Plant Physiology 149, 1601-1608.

Rennie, E.A., Turgeon, R., 2009. A comprehensive picture of phloem loading strategies. PNAS 106, 14162-14167.
Ruiz-Sanchez, M.C., Domingo, R., Castel, J.R., 2010. Review. Deficit irrigation in fruit trees and vines in Spain. Spanish Journal of Agricultural Research 8, 5-20.

Schaap, M.G., Leij, F.J., van Genuchten, M.Th., 2001. Rosetta: a computer program for estimating soil hydraulic parameters with hierarchical pedotransfer functions. Journal of Hydrology 251, 163-176.

Sperry, J.S., 2000. Hydraulic constraints on plant gas exchange. Agricultural and Forest Meteorology 2831, 1-11

Sperry, J.S., Adler, F.R., Campbell, G.S., Comstock, J.P., 1998. Limitation of plant water use by rhizosphere and xylem conductance: results from a model. Plant, Cell \& Environment 21, 347-359.

Sperry, J.S., Hacke, U.G., Oren, R., Comstock, J.P., 2002. Water deficits and hydraulic limits to water supply. Plant, Cell \& Environment 25, 251-264.

Sperry, J.S., Tyree, M.T., 1988. Mechanism of water stress-induced xylem embolism. Plant Physiology 88, 581-587.

Stahlberg, R., Van Volkenburgh, E., Cleland, R.E., 2001. Long-distance signaling within Coleus $\times$ hybridus leaves; mediated by changes in intra-leaf $\mathrm{CO}_{2}$ ? Planta 213 , 342-351.

Tognetti, R., Giovannelli, A., Lavini, A., Morelli, G., Fragnito, F., d'Andria, R. 2009. Assessing environmental controls over conductances through the soil-plant-atmosphere continuum in an experimental olive tree plantation of southern Italy. Agricultural and Forest Meteorology 149, 1229-1243.

Tyree, M.T., Dixon, M.A., 1986. Water stress induced cavitation and embolism in some woody plants. Physiologia Plantarum 66, 397-405.

Vico, G., Porporato, A., 2008. Modelling C3 and C4 photosynthesis under waterstressed conditions. Plant and Soil 313, 187-203.

Villalobos, F.J., Orgaz, F., Mateos, L., 1995. Non-destructive measurement of leaf area in olive (Olea europaea L.) trees using a gap inversion method. Agricultural and Forest Meteorology 73, 29-42.

Zufferey, V., Cochard, H., Ameglio, T., Spring, J.-L., Viret, O., 2011. Diurnal cycles of embolism formation and repair in petioles of grapevine (Vitis vinifera $\mathrm{cv}$ Chasselas). Journal of Experimental Botany 62, 3885-3894. 